\title{
Size Effect of Welded Thin-Walled Tubular Joints
}

\author{
Fidelis Rutendo Mashiri ${ }^{1 *}$, Xiao-Ling Zhao ${ }^{1}$ Manfred A. Hirt ${ }^{2}$ and Alain Nussbaumer ${ }^{2}$ \\ ${ }^{\text {I}}$ Department of Civil Engineering, Monash University, Clayton, VIC. 3800, AUSTRALIA \\ ${ }^{2}$ Department of Civil Engineering, Ecole Polytechnique Federale de Lausanne, CH-1015, Lausanne, Switzerland
}

\begin{abstract}
:
This paper clarifies the terminologies used to describe the size effect on fatigue behaviour of welded joints. It summarizes the existing research on size effect in the perspective of newly defined terminologies. It identifies knowledge gaps in designing tubular joints using the hot spot stress method, i.e. thin-walled tubular joints with wall thickness less than $4 \mathrm{~mm}$ and thick-walled tubular joints with wall thickness larger than $50 \mathrm{~mm}$ or diameter to thickness ratio less than 24 . It is the thin-walled tubular joints that are addressed in this paper. It is found out that thin-walled tube-to-plate T-joints do not follow the conventional trend: the thinner the section is, the higher the fatigue life. It is also found out that simple extrapolation of existing fatigue design curves may result in unsafe design of thin-walled tube-to-tube T-joints. The effect of chord stiffness on the fatigue behaviour of thin-walled tubular T-joints is also discussed.
\end{abstract}

KEYWORDS: Size effect, Thickness effect; welded joints; plate; tube; weld defects; fatigue

\footnotetext{
* Corresponding Author. Tel.:+61-3-9905 5579; Fax:+61-3-99054944; Email: fidelis.mashiri@eng.monash.edu.au, Department of Civil Engineering, Monash University, Wellington Rd, Clayton, VIC. 3800, Australia
} 


\section{INTRODUCTION}

Fatigue life of welded joints depends on many parameters. Some of the parameters which influence fatigue life are among others, wall thickness of plates or tubes, weld shape and size, residual stress field and non-dimensional parameters of a connection. The wall thickness is sometimes regarded as the most important parameter when comparing the relative fatigue life of two welded joints, hence the term "thickness effect" is widely used in the literature ${ }^{1-5}$ and the term "thickness correction factor" is used in various standards ${ }^{6-8}$. Other terms that are also found in the literature are "size effect", "scaling effect" and "geometrical effect" 5,9,10. In addition to the aforementioned parameters, fatigue life of welded connections is also influenced by post weld treatment ${ }^{11,12}$ and the environment condition ${ }^{13-15}$.

This paper attempts to clarify the terminologies. It briefly summarizes some of the previous research dealing with size effect. The newly defined terminologies are used to examine each research. The size effect in existing design recommendations for some tubular joints is summarized in the format of both classification method and hot spot stress method. The existing design recommendation based on hot spot stress method ${ }^{16,17}$ does not cover tubular joints with wall thickness less than $4 \mathrm{~mm}$ or larger than $50 \mathrm{~mm}$ or with $2 \gamma$ value less than 24 . The tubular joints with $\mathrm{t}<4 \mathrm{~mm}$ is called thinwalled tubular joints while those with $\mathrm{t}>50 \mathrm{~mm}$ or $2 \gamma<24$ are called thick-walled tubular joints in this paper. Reports on the thick-walled tubular joints can be found in Schumacher ${ }^{18}$ and Schumacher et al ${ }^{19}$. Only the thin-walled tubular T-joints are addressed in this paper. The conventional trend in fatigue S-N curve will be verified for such thin-walled tube-to-plate T-joints. The suitability of simply extrapolating existing fatigue design S-N curves for thin-walled tube-to-tube joints will be checked. Discussions are also made on the effect of chord stiffness on the fatigue behaviour of thin-walled tubular Tjoints.

\section{TERMINOLOGIES}

Different terminologies were used in the literature when comparing the fatigue behaviour of welded joints. This section aims to clarify the concept and define the new terminologies.

Fatigue life of welded joints may be affected by connection size and improvement technology. The fatigue life of welded connections can therefore be classified as influenced by two main components, i.e. size effect and improvement effect. The 
size effect includes statistical size effect, technological size effect and geometrical size effect. These three effects can be represented or studied quantitatively using a scaling effect when comparing the fatigue behaviour of two welded joints. Details are explained below.

\subsection{SIZE EFFECT}

\subsubsection{Statistical Size Effect}

Size effect in fatigue may be interpreted using the so-called statistical effect which stems from the fact that fatigue is a weakest link process, nucleating at the location where stresses, geometry, defects and material properties combine to form optimum conditions for fatigue crack initiation and growth. Increasing the size of a specimen will statistically produce locations that are more vulnerable to fatigue failures ${ }^{19}$. Örjasaeter et $a l^{20}$ termed the statistical effect, the volume effect, and interpreted it as a correlation between the volume of highly stressed material and fatigue strength. A possibility to consider this effect is based on the weakest link theory proposed by Weibull ${ }^{21}$ and Savaidis et al ${ }^{22}$. Fatigue tests of welded joints are influenced by the initiation and growth of small ellipsoidal cracks from the weld toe. The length of the weld toe from which the cracks initiate is therefore an influencing factor for fatigue strength since a larger length results in more likelihood of initiation and failure of the welded joint ${ }^{23}$.

\subsubsection{Technological Size Effect}

Technological size effect results from differences in production parameters. For example, due to differences in rolling reduction ratios, the mechanical properties diminish with increasing plate thickness. This effect can be neglected if mechanical properties are essentially the same for different thicknesses. Technological size effect can be considered to occur as a result of varying residual stresses caused by welding in different plate thicknesses. Technological size effect can also be understood in terms of geometrical size effect at the mesoscale level, which originates from incomplete scaling. When all dimensions are scaled up or down equally, the material properties such as grain size, flaw dimensions and mechanical properties do not change ${ }^{23}$.

\subsubsection{Geometrical Size Effect (at the mesoscale level)}

A model can be used for explaining the thickness effect in welded joints where fatigue cracks initiate from the weld toes ${ }^{1,13}$. In this model the following assumptions are adopted; (i) Welded joints of the same type in various plate thicknesses are 
geometrically similar. This is typical of load-carrying welded joints, (ii) Initial conditions of fatigue crack growth are independent of plate thickness. This means that the initial cracks in welds of different thicknesses are of the same magnitude. Therefore the stress distribution across the load-carrying plates in the crack growth plane are geometrically similar, leading to a steeper stress gradient in the thinner joint, according to assumption (i). Using assumption (ii), the initial crack in the thinner plate will experience a smaller stress than the initial crack of the same length in the thicker plate. This results in a smaller initial crack growth in the thinner joint ${ }^{4,19}$.

\subsection{SCALING EFFECT}

This paper introduces a new concept called "scaling effect". The scaling effect includes complete proportional scaling, practical proportional scaling and non-proportional scaling. Complete proportional scaling is defined as the case where all factors affecting fatigue are scaled proportionally, whatever their origin (statistical, technological or geometrical). Practical proportional scaling is defined as the case where only important factors are scaled proportionally. Non-proportional scaling is defined as the case where some important factors are not scaled proportionally. The more the parameters affecting the fatigue of a connection, the less chance to achieve a complete proportional scaling. In fact only very simple plated connection types (e.g. plate with transverse attachments) may achieve complete proportional scaling. For tubular joints, practical proportional scaling may be achieved if the important non-dimensional parameters $(\beta, \tau, 2 \gamma)$ are scaled proportionally. When thickness is the only parameter needed to describe the relative fatigue life of two joints, we call this case "complete" thickness effect. It only could happen under the condition of complete proportion of two joints. It is only possible for very simple welded joints such as transverse attachments. When thickness is one of the parameters needed to describe the relative fatigue life of two joints, we call the influence due to thickness "partial" thickness effect. When the influence of other parameters is insignificant, the "partial" thickness effect may be approximated as the "complete" thickness effect. In the expression describing the relative fatigue strength, there are two possible reference cases. When the reference thickness is the smaller one, it is called thickness correction factor, when it is the larger one, it is called thinness correction factor.

The flowchart in Fig. 1 shows the two categories that can influence fatigue life. The flowchart shows in detail the different concepts that form part of the size and improvement effects. 


\subsection{IMPROVEMENT EFFECT}

The improvement effect results from the enhancement in geometry and residual stress distribution within the welded connection due to post-weld treatments. The improvement of geometry in welded connections can result from processes such as weld toe grinding and TIG dressing. These processes cause a decrease in stress concentration due to the improved geometry at the toes of the weld, a result of a smoother and hence gradual transition between two welded plates or sections. The residual stress at weld toes can also be improved through processes such as hammer or shot peening which cause a reduction in tensile residual stresses or a change in residual stress at the locations of interest from tension to compression. More details can be found in Haagensen and Maddox ${ }^{12}$ as well as Walbridge et al ${ }^{24}$. The improvement effect thus influences all size effects (statistical, technological and geometrical), however at different degrees.

\section{EXISTING RESEARCH ON SIZE EFFECT}

Apart from the researchers mentioned in the previous sections, numerous researchers have investigated the size effect phenomenon from as early as the 1950s to this day. This research has led to a better understanding of the influence of plate and or tube-wall thickness on fatigue strength of welded connections. In his 1989 review, Gurney ${ }^{2}$ pointed out that thickness effect could be demonstrated using both fracture mechanics theory and experimental work. This had led to the introduction of a thickness correction factor in the revised version of the UK Department of Energy Guidance Notes in 1984. Gurney ${ }^{2}$ also noted that a lot earlier than the introduction of the thickness effect on fatigue of welded connections, Phillips and Heywood ${ }^{25}$ had demonstrated the size dependence of fatigue strength of unwelded specimens. Gurney ${ }^{2}$ also pointed out that it had long been known that plate thickness was likely to be a relevant variable for fatigue strength under bending stresses, because the stress gradient through the thinner specimen would be steeper and therefore less damaging than that in thicker specimens. Gurney ${ }^{26}$ showed with the use of fracture mechanics theory, that fatigue strength of welded joints could be affected by plate thickness even when they were subjected to axial loading. Gurney ${ }^{27}$ pointed out on the basis of fracture mechanics analysis and experimental evidence that the effect of plate thickness on fatigue strength could be significant.

Other researchers have also studied the behaviour of welded plate, tubular and tube-plate joints with different wall thicknesses. This research has either strengthened the concept of thickness effect or culminated in the introduction of 
thickness correction factors in various standards around the world. In the majority of the research on plated specimens, the main plate and transverse plates are usually of equal thickness.

When thickness effect is studied using main plate and transverse plates of equal thickness, the category of scaling can be referred to as practical proportional scaling. This is because the most important parameter influencing thickness effect, that is the wall thickness of the plate is scaled proportionally. However, although the thickness is scaled proportionally in plated joints, other parameters such as weld size, though normally increasing with increasing thickness to cope with an increase in applied design load, may not be proportionally scaled, in particular in non-load carrying welded connections. Other parameters that can also vary but not proportionally are the weld toe conditions such as weld toes radius and the residual stress magnitude due to welding. If the plate thickness, weld size, weld toe radius and residual stresses are increased proportionally from specimen to specimen, then complete proportional scaling is deemed to have occurred. This condition is difficult to achieve in real structures. When the main plate, transverse or longitudinal plate thickness, or dimensions are not directly linked with the applied design load, then we have a case of practical or non-proportional scaling.

Some of the existing research is summarized in Table 1 . The summary shows the type of joints tested, the load type applied and the thicknesses of the plates and tubes tested. The different loads applied confirm the fact that thickness effect is observed in joints regardless of the type of load to which the connection is subjected to. The category of scaling used in the studies is shown in Table 1 and the thickness correction factors suggested by some of the researchers are given as footnotes in Table 1.

Table 1 shows that most of the fatigue data that is used in deriving the thickness correction factors for welded plate joints comes from specimens with practical proportional scaling. For welded tubular nodal joints, non-proportional scaling mainly occurs. Practical proportional scaling and non-proportional scaling results in what is termed partial thickness effect as shown in Fig. 1. It can be seen that there are no studies on thin-walled tubular joints $(t<4 \mathrm{~mm})$ reported in Table, that is on what is called the thinness effect. This will be the subject of sections 5 to 7 of this paper. 


\section{SIZE EFFECT IN EXISTING DESIGN RECOMMENDATIONS FOR TUBULAR JOINTS}

\subsection{Classification Method}

Various standards around the world have adopted thickness correction factors or design S-N curves that depict thickness effect. Thickness correction factors are obtained by plotting the relative fatigue strength versus the thickness of the failing

member. Gurney ${ }^{2}$ obtained the relationship between fatigue strength and thickness of a member under failure by plotting the relative fatigue strength normalised to a reference thickness of $32 \mathrm{~mm}$ versus the thickness of different plate and tubular joints. Thickness correction factors have been adopted in standards such as those from the International Institute of Welding 8,16 , the British Standards ${ }^{7,35}$, the European Standard ${ }^{36}$, CIDECT Design Guide No. $8{ }^{17}$ and Australian Standard ${ }^{6}$, with however different values for the reference thickness. The thickness correction factors can be used to predict the fatigue strength of wall thicknesses other than the reference thickness.

Table 3 shows the size effect in tubular connections in some existing standards in the format of classification method. In the classification method, the fatigue strength of a constructional detail relates the nominal stress range, due to the applied member loads, to the number of cycles to failure. The first example in Table 2 (fillet welded circular hollow sections) may be approximated as the case of complete thickness effect. The other two examples in Table 2 may be considered as "partial thickness effect" because the fatigue life is also influenced by manufacturing method for the second example or other nondimensional parameters for the third example.

\subsection{Hot Spot Stress Method}

The hot spot stress method relates to the hot spot stress range to the number of cycles to failure. The fatigue design curves from CIDECT Design Guide No. $8^{17}$ and IIW ${ }^{16}$ are shown in Fig. 2 with some explanation given in Table 3. It can be seen from Table 3 that the size effect may be considered "partial thickness effect" because other parameters also influence the fatigue life. It is also interesting to note that the thickness correction factor in Table 3 also depends on the number of cycles to failure $(\mathrm{N})$. This stems from the fact that in the low cycle fatigue range, thickness effect is less pronounced ${ }^{37}$. Thickness effect therefore tends to be pronounced as the number of cycles to failure increases.

Figure 2 shows the current limitations of the fatigue design curves in IIW ${ }^{16}$ and CIDECT Design Guide No. $8^{17}$. The limitations in these standards, as shown in Fig. 2, are such that there are no fatigue design curves for thin-walled tubular 
joints $(\mathrm{t}<4 \mathrm{~mm})$ and for thick-walled joints $(\mathrm{t}>50 \mathrm{~mm}$ or $2 \gamma<24)$. This paper addresses the size effect of thin-walled tubular joints in the next sections (sections 5 to 7). The size effect in nodal joints made up of relatively thick-walled tubular connections was reported by Schumacher ${ }^{18}$. A more comprehensive study on size effect in welded thick-walled joints was complied and reported by Schumacher et al ${ }^{9}$.

\section{SIZE EFFECT OF WELDED THIN TUBE TO PLATE T-JOINTS}

There has been an increased availability in high strength cold-formed steel tubes in different steel markets around the world 38-42. This has led to the use of these tubes, which are mainly thin-walled, in the manufacture of equipment and construction

of structural systems some of which are subjected to cyclic loading ${ }^{43-45}$. The lack of fatigue design rules for welded tubes of wall thicknesses less than $4 \mathrm{~mm}$ has prompted interest among researchers to investigate their fatigue strength.

An investigation into the fatigue strength of welded thin-walled circular hollow section to plate (CHS-Plate) and square hollow section to plate (SHS-Plate) T-joints was carried out at Monash University and reported by Mashiri et al ${ }^{43,44}$ and Mashiri and Zhao ${ }^{46}$. Thin-walled circular hollow section (CHS) and square hollow section (SHS) tubes were welded onto $10 \mathrm{~mm}$ thick plates and the resulting CHS-Plate and SHS-Plate T-joints subjected to cyclic in-plane bending moment through the CHS or SHS brace as shown in Fig. 3. Specimens were tested at a stress ratio of 0.1 .

The parameters in tube-to-plate T-joints that are likely to contribute to the fatigue strength are the thickness of the plate T, the thickness of the tube, $t_{1}$, and the weld size and weld toe conditions. Compared to the tube wall thicknesses which ranged between $1.6 \mathrm{~mm}$ and $3.0 \mathrm{~mm}$, the plate thickness of $10 \mathrm{~mm}$ is significantly large. Since no cracks occurred in the plate, the plate thickness can be considered to have negligible influence on the fatigue strength of the tube-to-plate T-joints except to provide a rigid base upon which the tube could bend. Research has shown that in welded thin-walled $(\mathrm{t}<4 \mathrm{~mm})$ joints, the welds are oversized ${ }^{47}$. For tube wall thicknesses less than $4 \mathrm{~mm}$, the weld size is oversized but constant since only a minimum size of weld can be deposited during welding. Since the plate and weld sizes are constant in this investigation, the main parameter influencing fatigue life is the tube wall thickness, $t_{1}$. In this study, the changing of the tube wall thickness $\left(\mathrm{t}_{1}\right)$ can be considered as practical proportional scaling. The comparison of the fatigue strength at different tube wall thickness, in this investigation, therefore represents a partial thickness effect as shown in Fig. 1. 
Tubes of different wall thicknesses were used in making the tube-plate T-joint specimens. For the thin CHS-Plate T-joints, circular hollow sections of thicknesses equal to 2.0, 2.6 and 3.2mm were used. For the thin SHS-Plate T-joints, square hollow sections of thicknesses equal to 1.6, 2.0, and 3.0mm were used. Since failure of the tube-plate T-joints occurred in the tubular brace members, the relative fatigue strength of the welded tubes with different wall thicknesses can be assessed. The fatigue strength of the welded thin-walled tubes with different wall thicknesses can be used to verify the thickness effect in welded thin-walled joints and compare it with existing trends in thickness effect for relatively thicker joints with wall thicknesses typically greater than $25 \mathrm{~mm}$ for plated joints and greater than $4 \mathrm{~mm}$ for tubular joints.

Figs. 4 and 5 show the mean S-N curves for welded thin-walled tube-plate T-joints made up of different tube wall thicknesses for the SHS-Plate and CHS-Plate T-joints respectively. In the regression analyses, a slope coefficient of 3 has been imposed. Figs. 4 and 5 show that for welded thin-walled $(t<4 \mathrm{~mm})$ tubes the fatigue strength decreases as the welded tube failing due to fatigue loading becomes thinner. This is not considered in design codes such as AS4100-1998 ${ }^{6}$, EC3 ${ }^{36}$, Department of Energy ${ }^{7}$ and Hobbacher ${ }^{8}$ and the new fatigue design guidelines on nodal tubular joints using the hot spot stress method IIW ${ }^{16}$ and Zhao et al ${ }^{17}$. It should also be noted that the thicknesses of tubes used in the manufacture of the thin-walled CHS-Plate and SHS-Plate T-joints, are outside the range of application of the thickness correction factors given in existing codes. The decrease in fatigue strength, shown in Figs. 4 and 5, as the tube wall thickness becomes smaller, for tube wall thicknesses below 4mm, can be attributed to the greater negative impact of weld toe defects such as undercut on fatigue crack propagation life of thin-walled $(\mathrm{t}<4 \mathrm{~mm})$ joints as reported by Mashiri et al ${ }^{43,48}$. Previous research by

Noordhoek et al ${ }^{49}$ reported on a similar phenomenon and attributed it to the difficulty associated with the welding of smaller wall thickness sections.

\section{SIZE EFFECT OF WELDED THIN TUBE TO TUBE T-JOINTS}

A study into the fatigue strength of welded thin-walled SHS-SHS, CHS-SHS and and CHS-CHS T-joints under cyclic inplane bending as shown in Fig. 6, was recently carried out at Monash University and reported by Mashiri et al ${ }^{45,48}$. The SHS-SHS T-joints were made up of square hollow section (SHS) chords of 3mm thicknesses as well as SHS braces of thicknesses $3 \mathrm{~mm}, 2 \mathrm{~mm}$ and $1.6 \mathrm{~mm}$. The CHS-SHS T-joints were made up of $3 \mathrm{~mm}$ thick square hollow section chords and circular hollow section braces of thicknesses $2 \mathrm{~mm}, 2.3 \mathrm{~mm}, 2.6 \mathrm{~mm}$ and $2.9 \mathrm{~mm}$. For the CHS-CHS T-joints, the chord 
members were $3.2 \mathrm{~mm}$ thick circular hollow sections whereas the brace members were of thicknesses $2.0 \mathrm{~mm}, 2.3 \mathrm{~mm}$, $2.6 \mathrm{~mm}$ and $3.2 \mathrm{~mm}$.

The range of parameters for the tube-to-tube T-joints tested are shown in Fig. 6. The parameters given in Fig. 6 include the thickness and the non-dimensional parameters. The non-dimensional parameters are, the brace to chord width/diameter ratio, $\beta$, the chord width/diameter to chord wall thickness ratio, $2 \gamma$; and the brace to chord wall thickness ratio, $\tau$. These parameters are not proportionally scaled. According to Fig. 1, this investigation can be referred to as involving nonproportional scaling. The study in tubular nodal joints therefore deals with partial thickness correction. About 100 tests were carried out.

Fatigue failure occurred in the 3mm SHS chords for SHS-SHS and CHS-SHS T-joints and hence the critical thickness for the S-N data obtained was $3 \mathrm{~mm}$. The critical tube wall thickness in the CHS-CHS T-joints is $3.2 \mathrm{~mm}$ since failure only occurred in the $3.2 \mathrm{~mm}$ thick chords. The resulting S-N data from this investigation was analysed using the hot stress method and compared to existing fatigue design guidelines for tubular nodal joints.

Fig. 7 presents the existing $\mathrm{S}_{\mathrm{r} . h \mathrm{~s}}-\mathrm{N}$ design curves for tubular nodal joints from the CIDECT Design Guide No. $8{ }^{17}$ and IIW 16. The existing $\mathrm{S}_{\mathrm{r} . h \mathrm{~h}}-\mathrm{N}$ curves show that for a given hot spot stress range, fatigue life increases as the thickness of the member failing under fatigue loading becomes smaller. This trend is in agreement with the conventional concept of thickness effect. The equations that can be used to determine the design $\mathrm{S}_{\mathrm{r} . h \mathrm{hs}}-\mathrm{N}$ curves for the different tube wall thicknesses in tubular nodal joints are those derived by van Wingerde et al ${ }^{5}$ and shown in Table 3 , which however are limited to tubes with $\mathrm{t}>4 \mathrm{~mm}$.

Using the current trend in CIDECT Design Guide No. $8{ }^{17}$ and IIW ${ }^{16}$, the extrapolated design $\mathrm{S}_{\text {r.hs }}-\mathrm{N}$ curve for a critical thickness of 3mm is shown in Fig. 7. It can be seen that the fatigue test data for the CHS-CHS, CHS-SHS and SHS-SHS Tjoints are much lower than the extrapolated IIW curve with $t$ of $3 \mathrm{~mm}$. It seems that simply extrapolating the existing S-N curve results in unsafe design of thin-walled tubular joints. The reduced fatigue life of welded thin-walled specimens can be attributed to the greater negative impact of weld toe undercut on fatigue crack propagation life as reported in Mashiri et al 
50,51. Note that the tube wall thicknesses in the tested thin CHS-CHS, CHS-SHS and SHS-SHS T-joints all lie outside the validity range of the thicknesses currently covered by CIDECT Design Guide No. $8{ }^{17}$ and IIW ${ }^{16}$.

\section{EFFECT OF CHORD STIFFNESS IN T-JOINTS}

\subsection{General}

T-joints of different stiffness have been tested during the investigations on fatigue of thin-walled joints. They are tube-toplate, tube-to-tube and concrete-filled chord T-joints as shown in Figure 8 with their corresponding range of parameters.

Fig. 9 shows the moment-angle of inclination graphs of SHS-SHS, SHS-Plate and SHS-SHS concrete-filled chord T-joints. The SHS-Plate T-joints have the highest stiffness of the three joints followed by the SHS-SHS concrete-filled chord Tjoints. The SHS-SHS T-joints are the least stiff of the three joint types. The stiffest joint has the highest moment-angle of inclination ratio in the linear elastic part of the curve. The stiffest joint also has the largest static strength. The service loads that a connection can carry are dependent on the static strength of the connection. Since the service loads applied to a structure determines the service life of a connection under cyclic loading, the stiffness of a connection is therefore likely to be a factor that influences the fatigue strength of a joint.

\subsection{Stress Concentration Factors in joints of different stiffness}

The maximum experimental stress concentration factors (SCFs) for the concrete-filled chord and the empty SHS-SHS Tjoints under in-plane bending in the brace are shown in Table 4. The maximum SCFs in the tubular nodal T-joints occur at weld toes in the chord ${ }^{52}$. Table 4 shows that for joints with the same non-dimensional parameters the concrete-filled chord T-joints have a smaller stress concentration factor compared to the SHS-SHS T-joints. The lower SCFs in the concretefilled chord T-joints can be attributed to the increased rigidity and reduced chord face flexibility caused by the concrete infill in the chord member ${ }^{52}$. Table 4 also shows that the ratio of the maximum SCF in a welded composite tubular T-joint to the maximum SCF in an empty joint is less than 1, with values as low as 0.3 . However, an anomaly occurred in test series S6S1, where the maximum SCF in the welded composite tubular T-joint was larger than the maximum SCF in the corresponding empty joint. This may be attributed to errors in strain gauge placement and the sensitivity of the quadratic extrapolation method to smaller distances of extrapolation characteristic in thin-walled $(t<4 \mathrm{~mm})$ joints. Poor concrete filling in the vicinity of the strain gauge location may also result in this type of error. 
For thin SHS-Plate T-joints, the maximum stress concentration factors at the brace-plate interface were found to occur at weld toes in the square hollow section brace ${ }^{43}$. The stress concentration factors are summarized in Table 5 . Table 5 shows that the maximum SCFs obtained in thin SHS-Plate T-joints were less than 2. This observation points to the fact that joints which are stiffer have smaller SCFs. The smaller magnitude of the SCFs in stiffer joints means that they will inherently have a better fatigue life.

\subsection{Fatigue life of joints with different stiffness}

The fatigue S-N data for the welded composite tubular T-joints is plotted in Figure 10 together with the S-N data from empty hollow section SHS-SHS T-joints and that of thin SHS-Plate T-joints in the format of classification method. The first observation is that the concrete filled SHS-SHS T-joints data do not follow well the S-N curve slope, imposed as 3 in the regression. Figure 10 shows that on average the welded composite tubular T-joints have a better fatigue life compared to the empty SHS-SHS T-joints. The S-N data for the welded composite tubular T-joints lie either above the S-N data plots for the empty SHS-SHS T-joints or on the upper bound of the scatter for the empty SHS-SHS T-joints. Figure 10 shows that the lower bound curve for concrete-filled chord T-joints under bending has a class (stress range at 2 million cycles) that is about 1.25 that of empty SHS-SHS T-joints. In terms of fatigue life, the welded composite tubular T-joints have about 2 times the fatigue life of empty SHS-SHS T-joints under a given nominal stress range.

When compared to concrete-filled chord SHS T-joints, the lower bound curve for thin SHS-Plate T-joints has a class that is about 4.8 times that of concrete-filled chord SHS T-joints. In terms of fatigue life, the thin SHS-Plate T-joints have a service life that is about 100 times that of the composite SHS T-joints for a given nominal stress range.

\section{CONCLUSIONS}

The following observation and conclusions are made:

(a) A definition was given for scaling effect which includes complete proportional, practical proportional and nonproportional scaling. Complete thickness effect only occurs under the condition of complete proportional scaling.

(b) The study of size effect in welded plate joints generally occurs under practical proportional scaling thereby resulting in a partial thickness effect being obtained. However in circumstances where the weld and weld toes conditions are almost 
proportionally scaled, the category of scaling can be approximated to complete proportional scaling resulting in complete thickness effect.

(c) The study of size effect in welded tubular nodal joints occurs under non-proportional scaling resulting in a partial thickness being derived.

(d) More research needs to be undertaken to understand the trend of thickness effect in thicker walled joints, with tube wall thicknesses or $2 \gamma$ beyond the current validity range in fatigue design guidelines for welded tubular joints.

(e) The conventionally accepted phenomenon of size effect shows that fatigue strength increases as the thickness of the member failing under fatigue decreases. Recent research on welded thin-walled $(\mathrm{t}<4 \mathrm{~mm})$ tube-to-plate and tube-to-tube T-joints has however shown that below a thickness of $4 \mathrm{~mm}$, fatigue strength actually decreases as the member failing under fatigue becomes thinner. This observation in thin-walled joints can be attributed to the greater negative impact that weld toe defects such as undercuts have on fatigue crack propagation life.

(f) It has been demonstrated that boundary conditions have an effect on the relative fatigue strength of welded joints. Joints with a higher stiffness have a better fatigue life compared to joints of lower stiffness when subjected to the same nominal stress range.

\section{ACKNOWLEDGEMENTS}

The authors would like to thank Dr. Ann Schumacher at Swiss Federal Laboratories for Materials Testing and Research (EMPA) for her discussion on the terminologies described in this paper. The second author is grateful to ICOM, EPFL Lausanne for providing support during his sabbatical leave when part of this paper was prepared.

\section{REFERENCES}

1. Berge S. 1985, "On the effect of plate thickness in fatigue of welds", Engineering Fracture Mechanics, 21, pp. 423-435 2. Gurney T.R. 1989, "The influence of thickness on fatigue of welded joints-10 years on (a review of British work)", Proc $8^{\text {th }}$ Int Conf on Offshore Mech and Arctic Eng, Vol. III, The Hague, The Netherlands, March 19-23, 1989, pp 1-8 3. Vosikovsky O., Bell R., Burns D.J., and Mohaupt U.H. 1989, "Thickness effect on fatigue of welded joints-review of the Canadian Program", Proc 8th Int Conf on Offshore Mech and Arctic Eng, Vol. III, The Hague, The Netherlands, March 19-23, pp 9-19 
4. de Back J., van Delft D.R.V., and Noordhoek C. 1989, "The effect of plate thickness on fatigue life of welded tubular joints and flat specimens", Proc $8^{\text {th }}$ Int Conf on Offshore Mech and Arctic Eng, Vol. III, The Hague, The Netherlands, March 19-23, pp 31-37

5. van Wingerde A.M., van Delft D.R.V., Wardenier J. \& Packer J.P., 1997, "Scale Effects on the Fatigue Behaviour of Tubular Structures". Proc IIW Int Conf on Performance of Dynamically Loaded Welded Struct, July 14-15, San Francisco, U.S.A, pp. 123-135

6. SAA 1998, Steel Structures, Australian Standard AS 4100-1998, Standards Association of Australia, Sydney, Australia.

7. Department of Energy, 1990, "Offshore Installations: Guidance on design, construction and certification", Fourth Edition, London, HMSO, UK.

8. Hobbacher A. 1996, "Fatigue design of welded joints and components", Recommendations of IIW Joint Working Group XIII-XV, XIII-1539-96/XV-845-96, Abington Publishing, Cambridge, England

9. Schumacher A., Nussbaumer A., and Hirt M.A. 2003, "Fatigue behaviour of welded CHS bridge joints: emphasis on the effect of size", Tubular Structures X, Proc. 10 $10^{\text {th }}$ Int Symp on Tubular Struct, ISTS10, 18-20 September, Madrid, Spain, pp. 365-374

10. Smith, I.F.C. and Gurney, T.R. (1986), Changes in the Fatigue Life of Plates with Attachments Due to Geometrical Effects, Welding Research Suppliment, September issue, 244s - 250s

11. Wohlfahrt, H; Nitschke-Pagel, T; Zinn, W AF 1996: Improvement of the fatigue strength of welded joints by postweld treatment methods - a comparison of the results of high strength structural steels and high strength aluminium alloys, Welding in the World/Soudage dans le Monde, Vol.38, Nov.1996, pp.307-316.

12. Haagensen P.J. and Maddox S.J. 2005, "IIW Recommendations on Post Weld Improvement of Steel and Aluminium Structures", IIW Commission XIII, Working Group 2- Improvement Techniques, XIII-1815-00, Revised7 July 2005, Prague

13. Berge S. and Webster S.E. 1987, "The size effect on the fatigue behaviour of welded joints", Paper PS 8, Developments in Marine Technology 3, Proc. $3^{\text {rd }}$ Int Conf on Steel in Marine Struct, SIMS'87, Delft, The Netherlands, 15-18 June, pp 179-203

14. Xue Y., Xu J., Li H. and Li Y. 1990, "Influence of plate thickness on fatigue behaviour of welded joints in air and seawater", China Ocean Eng, Vol. 4, No. 2, pp.179-188 
15. Cole I.S., Vittori O. and Cerretti G. 1993, "Cathodic Protection and Thickness Effect: A Final Conclusion?", Proc. 3 rd Offshore and Polar Eng Conf, Singapore, June 6-11, pp 309-316

16. IIW 2000: Fatigue Design Procedures for Welded Hollow Section Joints, IIW Doc. XIII-1804-99, IIW Doc. XV1035-99, Recommendations for IIW Subcommission XV-E, Edited by X.L. Zhao and J.A. Packer, Abington Publishing, Cambridge, UK

17. Zhao X.L., Herion S., Packer J.A., Puthli R., Sedlacek G., Wardenier J., Weynand K., Wingerde A., and Yeomans N. 2000, "Design Guide for Circular and Rectangular Hollow Section Joints under Fatigue Loading", Verlag TUV Rheinland, Koln, Germany.

18. Schumacher A 2003, "Fatigue behaviour of welded circular hollow section joints in bridges", PhD Thesis No. 2727 , Department of Civil Engineering, Faculty of Built Environment and Architecture, Ecole Polytechnique Federale De Lausanne, Switzerland

19. Berge S. 1989, "The plate thickness effect in fatigue-predictions and results (A review of Norwegian work)", Proc. $8^{\text {th }}$ Int Conf on Offshore Mech and Arctic Eng, Vol. III, The Hague, The Netherlands, March 19-23, 1989, pp 21-30

20. Örjasaeter O., Drågen A., Haagensen P.J., Lian B and Gunleiksrud Å. 1987, "Effect of plate thickness on the fatigue properties of low carbon-micro-alloyed steel", Paper TS 6, Developments in Marine Technology 3, Proc. $3^{\text {rd }}$ Int Conf on Steel in Marine Struct, SIMS'87, Delft, The Netherlands, 15-18 June, pp 315-335

21. Weibull W. 1959: Zur Abhangigkeit der Festigkeit von der Probengrosse, Ingenieur Archiv, Vol. 28, pp.360-362

22. Savaidis G., Savaidis A., Tsamasphyros G. and Zhang Ch., 2002, "On size and technological effects in fatigue and prediction of engineering materials and components", International Journal of Mechanical Sciences, Vol. 44, pp.521543

23. Overbeeke J.L. and Wildschut H. 1987, "The influence of plate thickness on the endurance of welded joints", Paper TS 1, Developments in Marine Technology 3, Proc. $3^{\text {rd }}$ Int Conf on Steel in Marine Struct, SIMS'87, Delft, The Netherlands, 15-18 June, pp 247-257

24. Walbridge, S., Nussbaumer, A. and Hirt, M.A. 2003, "Fatigue behaviour of improved tubular bridge joints", 10 International Symposium on Tubular Structures, Madrid

25. Phillips C.E. and Heywood R.B. 1951, "The size effect in fatigue of plain and notched specimens loaded under reversed direct stress", Proc Inst of Mech Eng, Vol. 165, pp. 113-124

26. Gurney T.R. 1977, "Theoretical analysis of the influence of toe defects on the fatigue strength of fillet welded joints", Welding Institute Research Report 32/1977/E 
27. Gurney T.R. 1979, "The influence of thickness on the fatigue strength of welded joints", Paper 41, Proc $2^{\text {nd }}$ Int Conf on Behaviour of Offshore Struct, BOSS'79, Imperial College, London, England, 28-31 August 1979, pp. 523-534

28. Mohaupt U.H., Burns D.J., Kalbfleisch J.G., Vosikovsky O. and Bell R. 1987, "Fatigue crack development, thickness and corrosion effects in welded plate to plate joints", Paper TS 3, Developments in Marine Technology 3, Proc. $3^{\text {rd }}$ Int Conf on Steel in Marine Struct, SIMS'87, Delft, The Netherlands, 15-18 June, pp 269-280

29. Booth G.S. 1987, "The effect of thickness on the fatigue strength of plate welded joints ", Paper TS 2, Developments in Marine Technology 3, Proc. $3^{\text {rd }}$ Int Conf on Steel in Marine Struct, SIMS'87, Delft, The Netherlands, 15-18 June, pp $259-268$

30. Berge S., Eide O.I., Astrup O.C., Palm S., Wastberg S., Gunleiksrud A and Lian B. 1987, "Effect of plate thickness in fatigue of welded joints in air and in seawater", Paper TS 45, Developments in Marine Technology 3, Proc. $3^{\text {rd }}$ Int Conf on Steel in Marine Struct, SIMS'87, Delft, The Netherlands, 15-18 June, pp 799-810

31. Noordhoek C., van Delft D.R.V. and Verheul A. 1987, "The influence of plate thicknesses on the fatigue behaviour of welded plates up to $160 \mathrm{~mm}$ with an attachment or butt weld", Paper TS 4, Developments in Marine Technology 3, Proc.

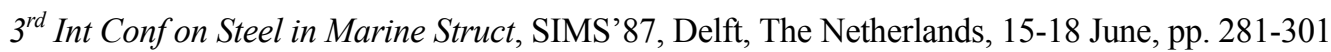

32. Eide O.I. and Berge S. 1987, "Fatigue of large scale plate girders with plate thicknesses 20, 40 and 60 mm", Paper TS 7, Developments in Marine Technology 3, Proc. $3^{\text {rd }}$ Int Conf on Steel in Marine Struct, SIMS'87, Delft, The Netherlands, 15-18 June, pp 337-347

33. van Delft D.R.V., Noordhoek C. and de Back J. 1985, "Evaluation of the European fatigue test data on large size welded tubular joints for offshore structures", Proc. $17^{\text {th }}$ Annual Offshore Tech Conf, Houston, Texas, OTC 4999, pp. $351-356$

34. IIW 2005:Recommendations for fatigue design of welded joints and components, IIW Doc. XIII-1965-03 / XV-112703, IIW Joints Working Group XIII-XV, IIW Annual Assembly, Prague

35. BSI 1993, Fatigue design and assessment of steel structures, BS7608, British Standards Institution, London, UK 36. EC3 2003, Eurocode 3: Design of Steel Structures-Part 1.9, Fatigue, European Committee for Standardisation, November 2003

37. van der Vegte G.J. 1998, "Low cycle fatigue of welded structures-Part C: Tubular T- and X-joints", Report Stevin Laboratory, Delft University of Technology, The Netherlands

38. Hancock G.J. 1999, "Recent research and design developments in cold-formed open section and tubular members", 
Proc. $2^{\text {nd }}$ Int Conf on Advances in Steel Struct, Vol. I, ICASS'99, Hong Kong, 15-17 December , pp. 25-37

39. ASTM 2001, Standard Specification for Cold-Formed Welded and Seamless Carbon Steel Structural Tubing in

Rounds and Shapes-Specification A500-01, American Society for Testing and materials, West Conshohocken, PA,

USA

40. SAA 1991, Structural Steel Hollow Sections, Australian Standard AS1163-1991, Standards Association of Australia, Sydney, Australia

41. CEN 1997, "Cold formed welded structural hollow sections of non-alloy and fine grain steels-Part 2: Tolerances, dimensions and sectional properties", EN10219-2: 1997, Committee for European Standardization (CEN), Brussels

42. STI 2001, Hollow Structural Sections-Principal Producers and Capabilities, Steel Tube Institute of North America, Mentor, Ohio, USA

43. Mashiri F.R., Zhao X.L., Grundy P. and Tong L. 2002, "Fatigue Design of Very Thin-Walled SHS-to-plate Joints under In-Plane Bending”, Thin-Walled Structures, Vol. 40, Issue. 2, pp. 125-151

44. Mashiri F.R., Zhao X.L. and Grundy P. 2002, "Fatigue Tests and Design of Thin Cold-Formed Square Hollow Section-to-Plate T-Connections under In-Plane Bending” J Struct Eng, ASCE, Vol. 128, No. 1, pp. 22-31

45. Mashiri F.R., Zhao X.L. and Grundy P. 2002, "Fatigue Tests and Design of Welded T-Connections in Thin ColdFormed Square Hollow Sections under In-Plane Bending” J Struct Eng, ASCE, Vol. 128, No. 11, Nov. 2002, pp. $1413-1422$

46. Mashiri F.R. and Zhao X.L. 2005, "Effect of Thickness and Joint Type on Fatigue Performance of Welded ThinWalled Tube-Plate T-Joints", Proceedings of The $1^{\text {st }}$ International Conference on Advances in Experimental Structural Engineering (AESE 2005), Editors: Itoh Y. and Aoki T. 19-21 July 2005, Nagoya, Japan, pp. 877-884

47. Zhao X.L and Hancock G.J. 1995, Butt Welds and Transverse Fillet Welds in Thin Cold-Formed RHS Members, Journal of Structural Engineering, ASCE, 121 (11), pp. 1674-1682

48. Mashiri F.R., Zhao X.L. and Grundy P. 2001, "Fatigue behaviour of thin-walled tube-to-tube T-joints under in-plane bending" Tubular Structures IX, Proc $9^{\text {th }}$ Int Symp and Euroconference on Tubular Struct, Düsseldorf, Germany, ISTS9, 3-5 April, pp. 259-268

49. Noordhoek C., Wardenier J. and Dutta D. 1980, "The fatigue behaviour of welded joints in square hollow sections-Part 2, Analysis", Stevin Report 6-80-4, TNO-IBBC Report BI-80-10/0063.4.3821, Department of Civil Engineering, Delft University of Technology, Delft, The Netherlands 
50. Mashiri F.R., Zhao X.L. and Grundy P. 1998, "Effects of Weld Undercut on the Fatigue Life of Welded Connections in Thin-Walled Structures" Proc Structural Integrity and Fracture, Australian Fracture Group Inc., 21-22 September Melbourne, Australia, pp. 81-91

51. Mashiri F.R., Zhao X.L. and Grundy P. 2001, "Effect of weld profile and undercut on fatigue crack propagation life of thin-walled cruciform joint" Thin-Walled Structures, Vol. 39, Issue 3, pp. 261-285

52. Mashiri F.R. and Zhao X.L. 2004, "Fatigue Behaviour of Welded Composite Tubular T-joints under In-Plane Bending", Thin-Walled Structures-Advances in Research, Design and Manufacturing, Proceedings of The $4^{\text {th }}$ International Conference on Thin-Walled Structures, Loughborough, United Kingdom, ICTWS4, Editor: Loughlan J., 22-24 June 2004, pp. 491- 498 


\section{NOTATION}

\begin{tabular}{|c|c|}
\hline $2 \gamma$ & $\left(=b_{0} / t_{0}\right)$ or $\left(=d_{0} / t_{0}\right)$, chord width or chord diameter to chord wall thickness ratio \\
\hline $\mathrm{t}$ & $=$ tube wall thickness \\
\hline$\tau$ & $\left(=t_{1} / t_{0}\right)$, brace wall to chord wall thickness ratio \\
\hline$\beta$ & $\left(=b_{1} / b_{0}\right),\left(=d_{1} / d_{0}\right)$, brace width to chord width ratio or brace diameter to chord diameter ratio \\
\hline $\mathrm{N}$ & $=$ number of cycles to failure \\
\hline$t_{0}$ & $=$ chord wall thickness \\
\hline$t_{1}$ & $=$ brace wall thickness \\
\hline SHS & $=$ square hollow section \\
\hline CHS & $=$ circular hollow section \\
\hline $\mathrm{S}$ & $=$ stress range \\
\hline $\mathrm{S}_{\mathrm{rhs}}$ & $=$ hot spot stress range \\
\hline $\mathrm{SCF}$ & $=$ stress concentration factor \\
\hline$b_{1}$ & $=$ brace width \\
\hline$b_{0}$ & $=$ chord width \\
\hline$d_{1}$ & $=$ brace diameter \\
\hline$d_{0}$ & $=$ chord diameter \\
\hline $\mathrm{S}_{\mathrm{r}-\mathrm{nom}}$ & $=$ nominal spot stress range \\
\hline $\mathrm{T}$ & $=$ plate wall thickness \\
\hline PWHT & $=$ post weld heat treatment \\
\hline $\mathrm{S}_{\mathrm{B}}$ & $=$ stress range of reference plate thickness $t_{B}$ \\
\hline$t_{B}$ & $=$ reference plate thickness \\
\hline $\mathrm{W}_{\mathrm{B}}$ & $=$ basic width corresponding to the basic design $\mathrm{S}-\mathrm{N}$ curve. \\
\hline $\mathrm{W}^{\prime}$ & $=$ apparent width of the plate under consideration \\
\hline HSSNR & $=$ hot spot strain range \\
\hline $\mathrm{N}_{\mathrm{c}}$ & $=$ number of cycles to through thickness crack \\
\hline
\end{tabular}




\begin{tabular}{|l|l|}
\hline $\mathrm{T}_{\text {cr }}$ & $=$ wall thickness of cracked member \\
\hline $\mathrm{S}_{\mathrm{rhs}, \mathrm{t}}$ & $=$ hot spot stress range for tube wall thickness, $\mathrm{t}$. \\
\hline $\mathrm{S}_{\text {rhs, } 16}$ & $=$ hot spot stress range for reference tube wall thickness, $\mathrm{t}=16 \mathrm{~mm}$ \\
\hline $\mathrm{t}_{\text {eff }}$ & $=$ effective thickness of main plate in cruciform type joints \\
\hline $\mathrm{SCF}_{\text {composite }}$ & $=$ stress concentration factor for SHS-SHS T-joint with concrete filled chord \\
\hline $\mathrm{SCF}_{\text {empty }}$ & $=$ stress concentration factor for empty SHS-SHS T-joint \\
\hline
\end{tabular}




\section{FIGURE CAPTIONS}

Fig. 1. Size and improvement effects and their corresponding concepts.

Fig. 2. Fatigue design curves for tubular nodal joints in standards ${ }^{16,17}$ and knowledge gaps identified

Fig. 3. (a) SHS-Plate and (b) CHS-PlateT-joints under cyclic in-plane bending (bolted to rigid plates)

Fig. 4. Effect of Tube Wall Thickness on Fatigue Life in Thin SHS-Plate T-joints

Fig.5. Effect of Tube Wall Thickness on Fatigue Life in Thin CHS-Plate T-joints

Fig. 6. (a) SHS-SHS, (b) CHS-SHS and (c) CHS-CHS T-joints under in-plane bending (simply supported at both ends)

Fig. 7. Existing Design $\mathrm{S}_{\mathrm{r} . \mathrm{hs}}-\mathrm{N}$ curves from IIW ${ }^{16}$ and fatigue test data for welded thin-walled $(\mathrm{t}<4 \mathrm{~mm})$ CHS-CHS, CHSCHS and SHS-SHS T-joints.

Fig. 8. (a) SHS-Plate (bolted to rigid plate), (b) Empty SHS-SHS (simply supported at both ends) and (c) Concrete-filled chord SHS-SHS T-joints under in-plane bending (simply supported at both ends)

Fig. 9. Applied bending moment vs angle of inclination in joints of different stiffness

Fig. 10. S-N data and lower bound curves for thin SHS-Plate, SHS-SHS and concrete-filled SHS-SHS T-joints

\section{TABLE CAPTIONS}

Table 1. Summary of Research on Size Effect

Table 2. Size effect in existing standards using classification method (some examples)

Table 3. Size effect in existing standards using hot spot stress method

Table 4. Experimental stress concentration factors in thin SHS-SHS T-joints and concrete-filled chord SHS T-joints under in-plane bending

Table 5. Experimental stress concentration factors for thin SHS-Plate T-joints 


\section{FIGURES}

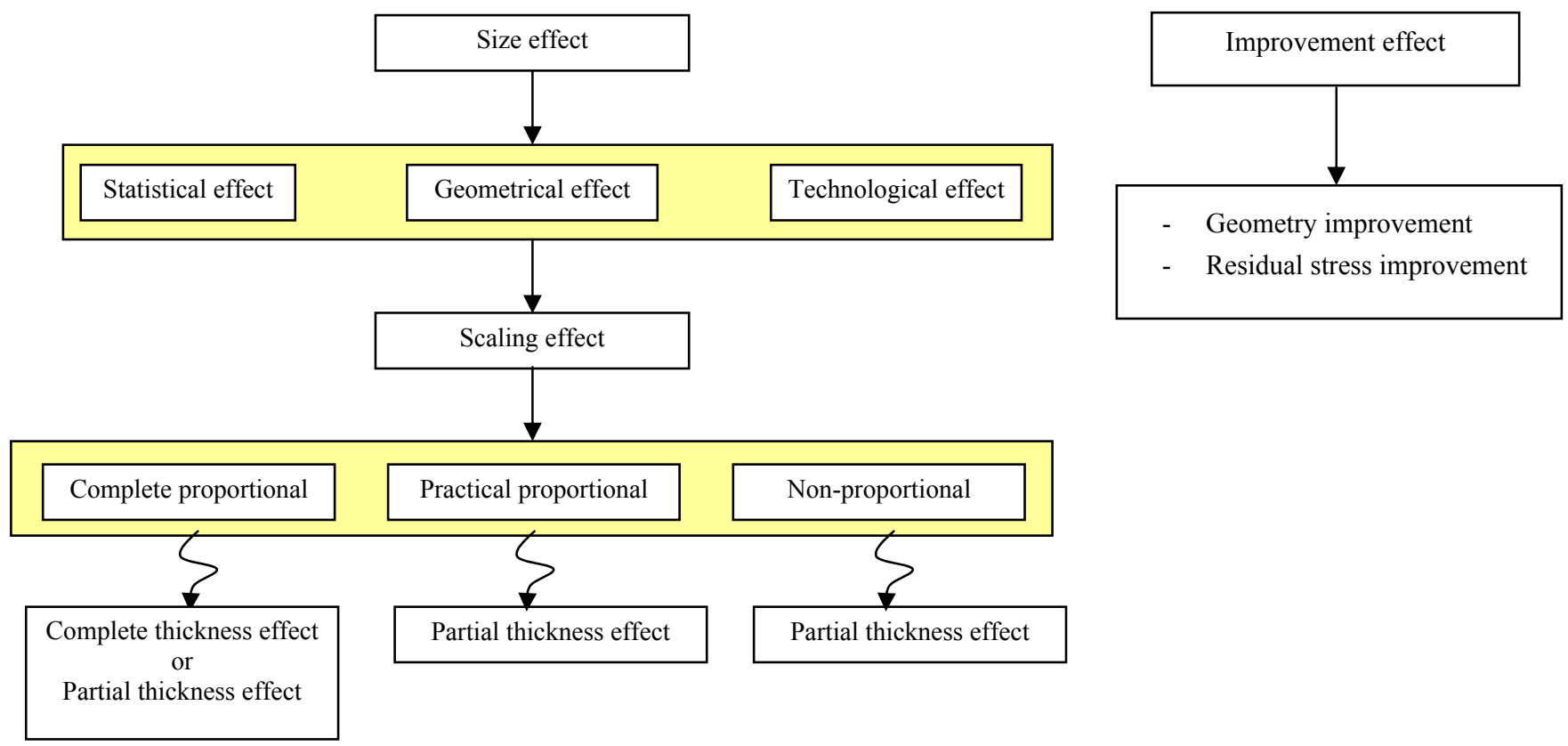

Fig.1. Size and improvement effects and their corresponding concepts.

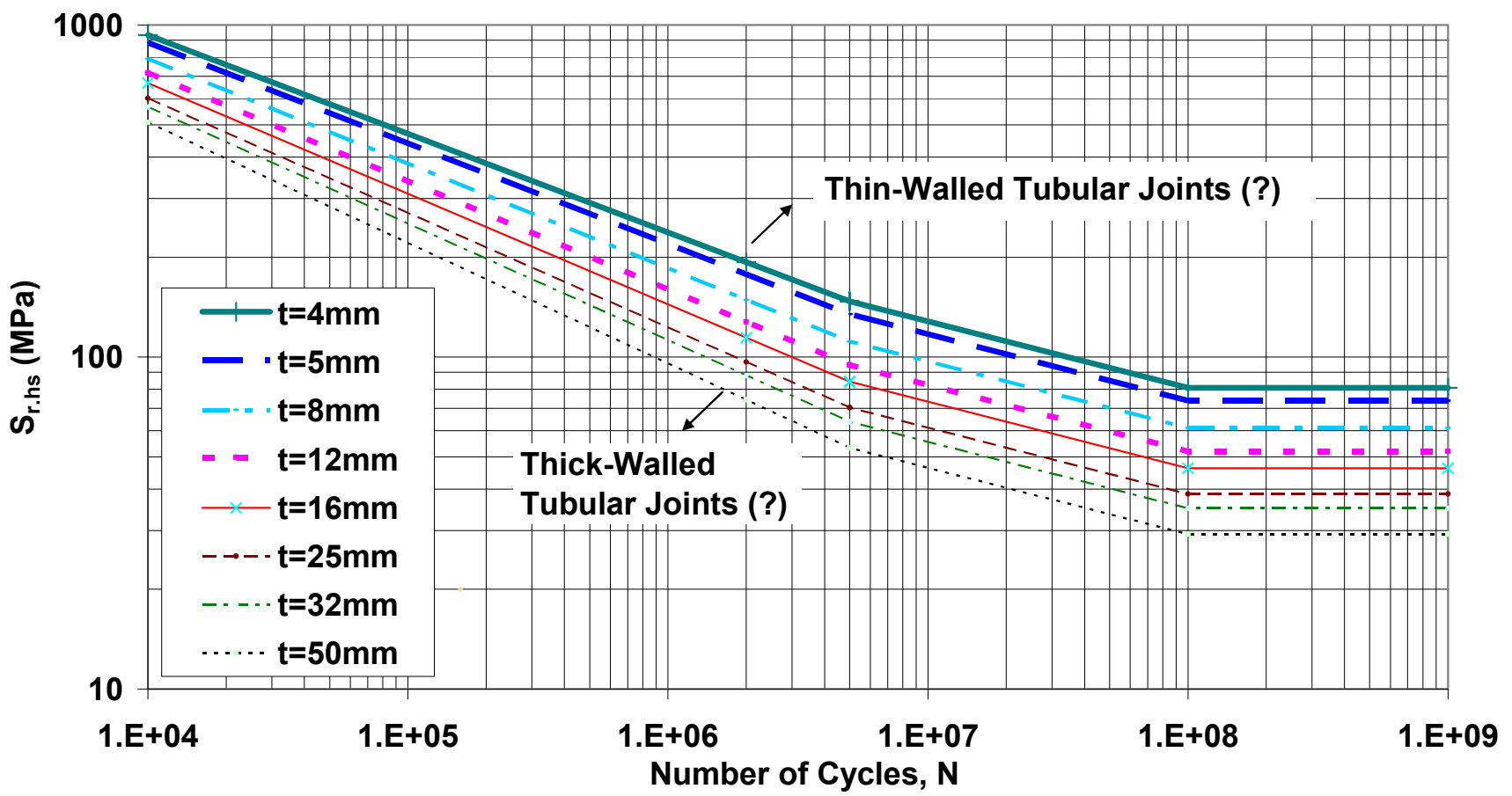

Fig. 2. Fatigue design curves for tubular nodal joints in standards ${ }^{16,17}$ and knowledge gaps identified 


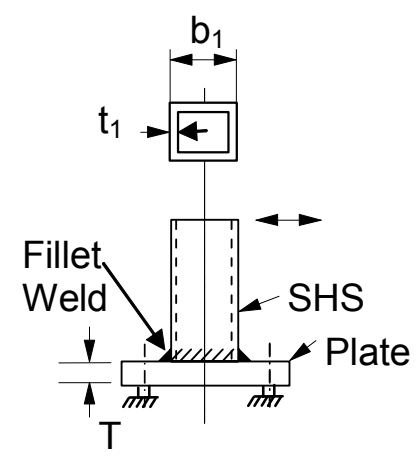

(a)

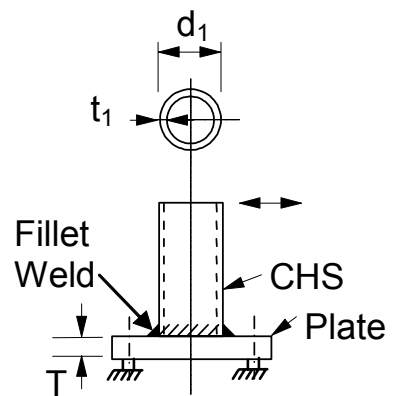

(b)

Fig. 3. (a) SHS-Plate and (b) CHS-PlateT-joints under cyclic in-plane bending (bolted to rigid plates)

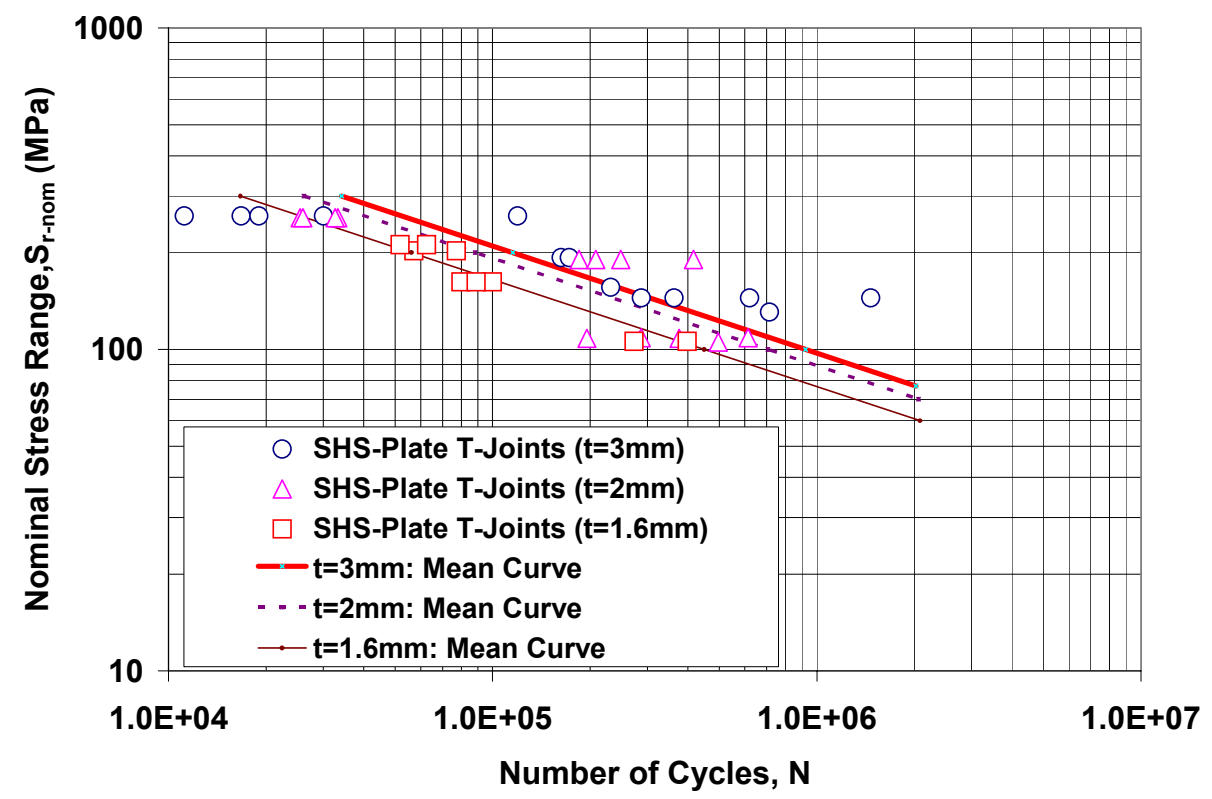

Fig. 4. Effect of Tube Wall Thickness on Fatigue Life in Thin SHS-Plate T-joints 


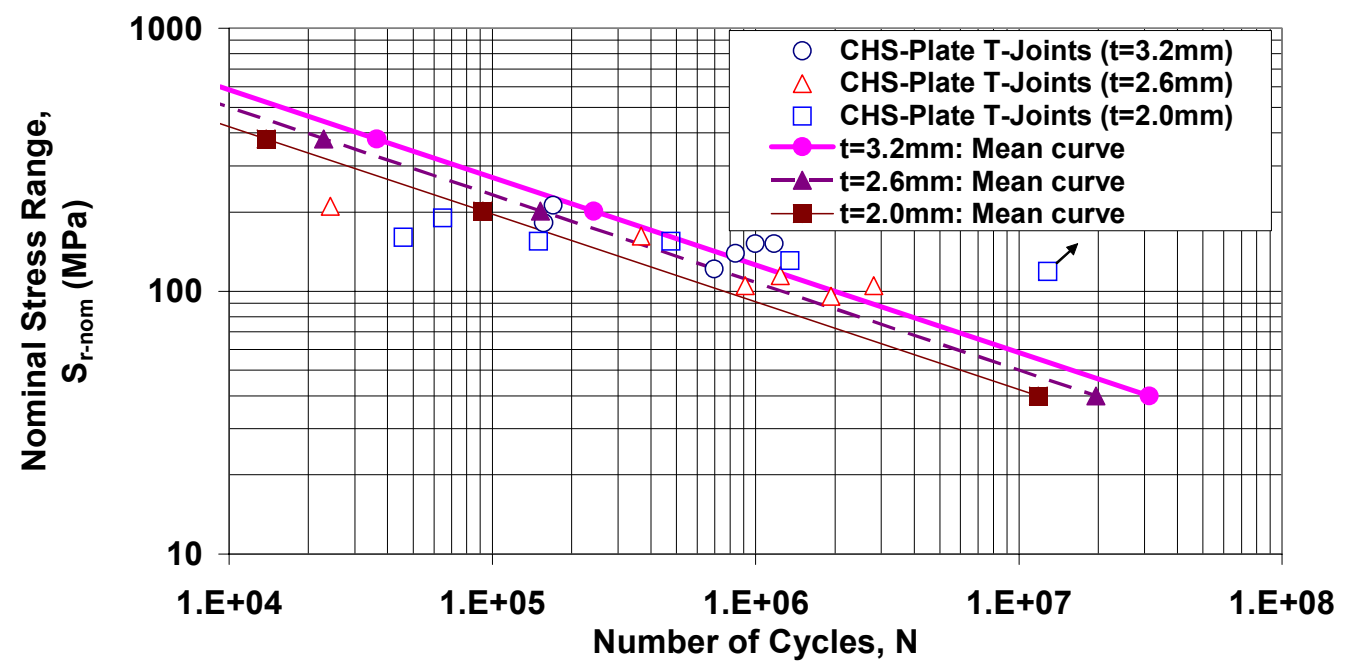

Fig. 5. Effect of Tube Wall Thickness on Fatigue Life in Thin CHS-Plate T-joints

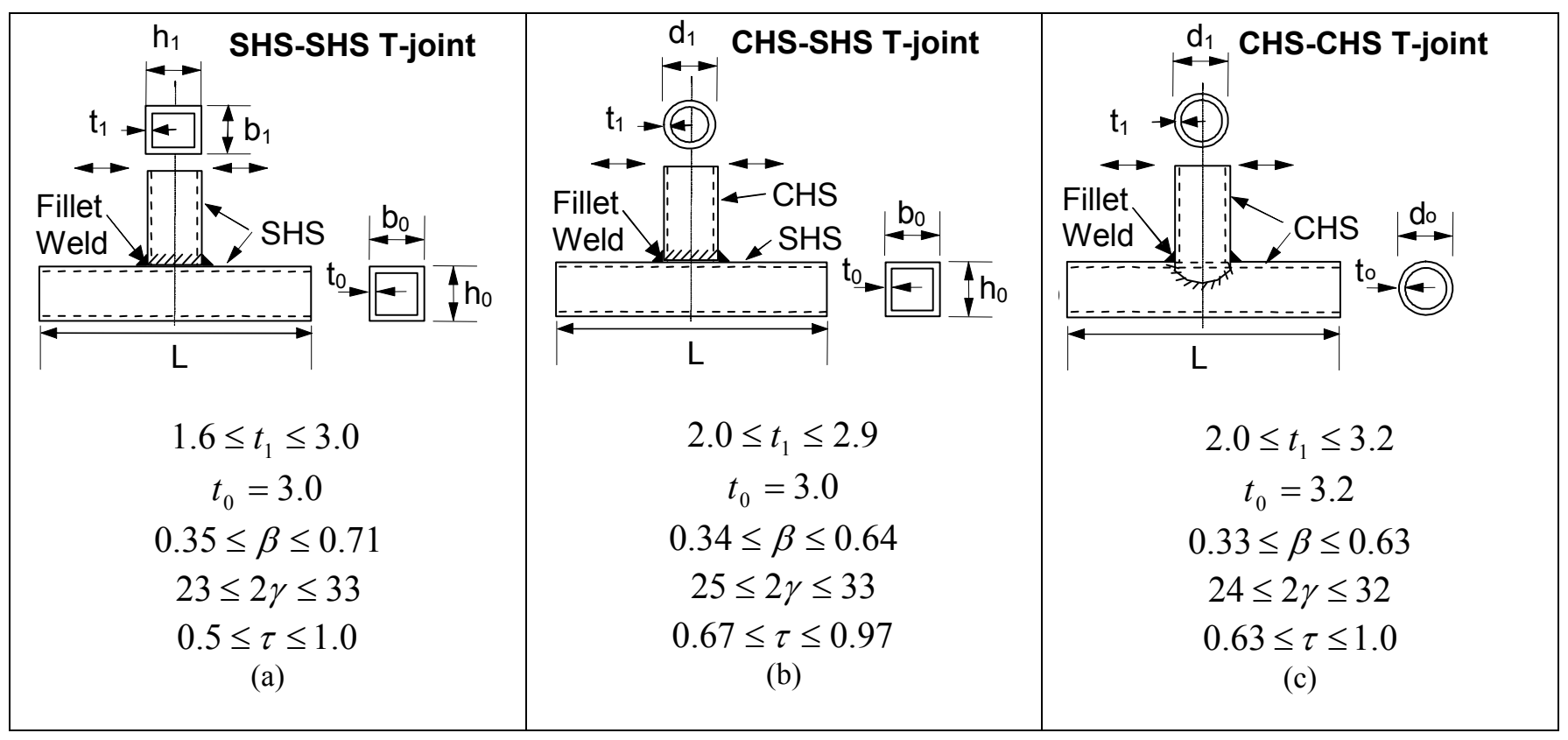

Fig. 6. (a) SHS-SHS, (b) CHS-SHS and (c) CHS-CHS T-joints under in-plane bending (simply supported at both ends) 


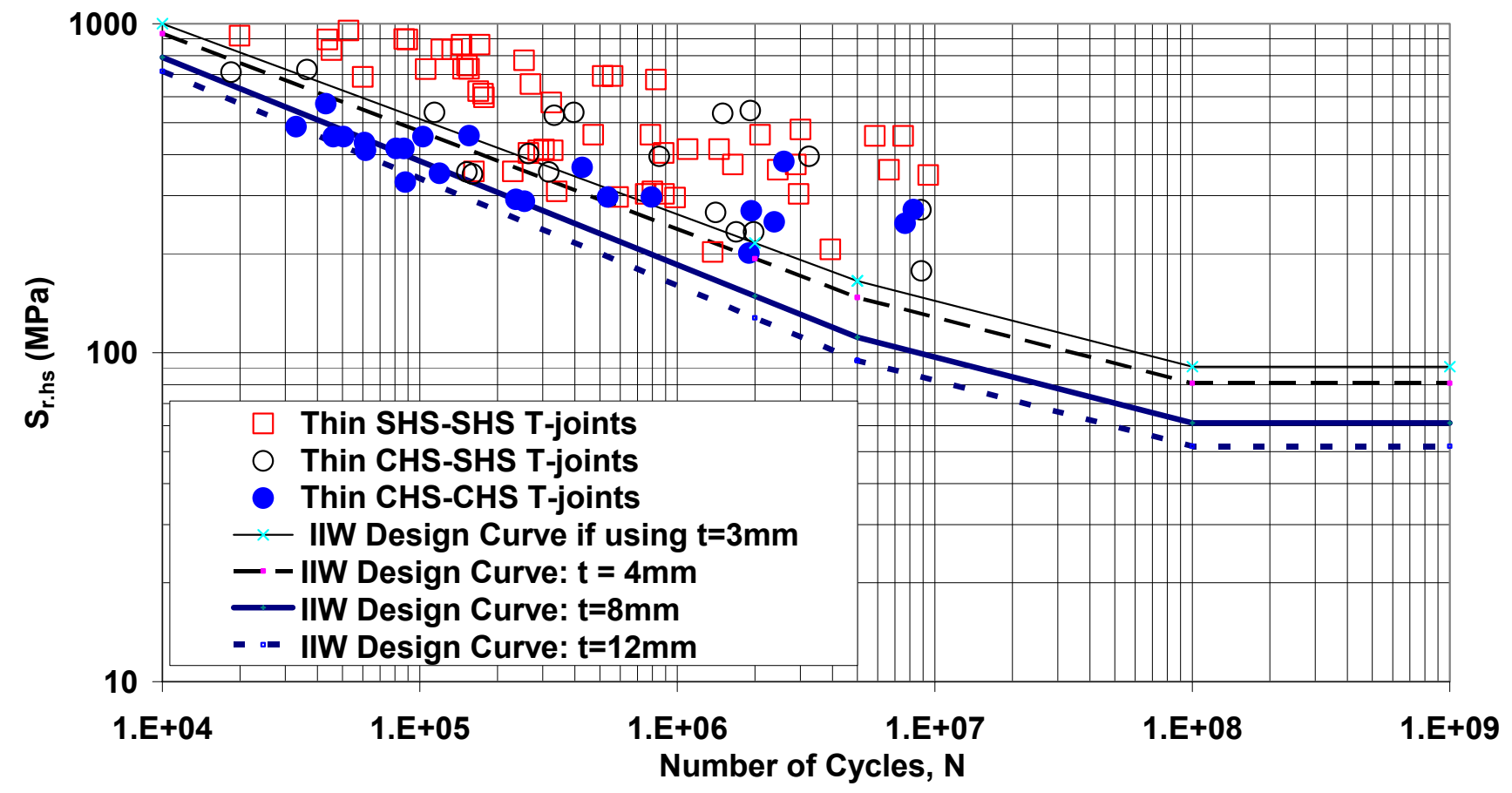

Fig. 7. Existing Design $\mathrm{S}_{\mathrm{r} . \mathrm{hs}}-\mathrm{N}$ curves from IIW ${ }^{16}$ and fatigue test data for welded thin-walled $(\mathrm{t}<4 \mathrm{~mm})$ CHS-CHS, CHSCHS and SHS-SHS T-joints.

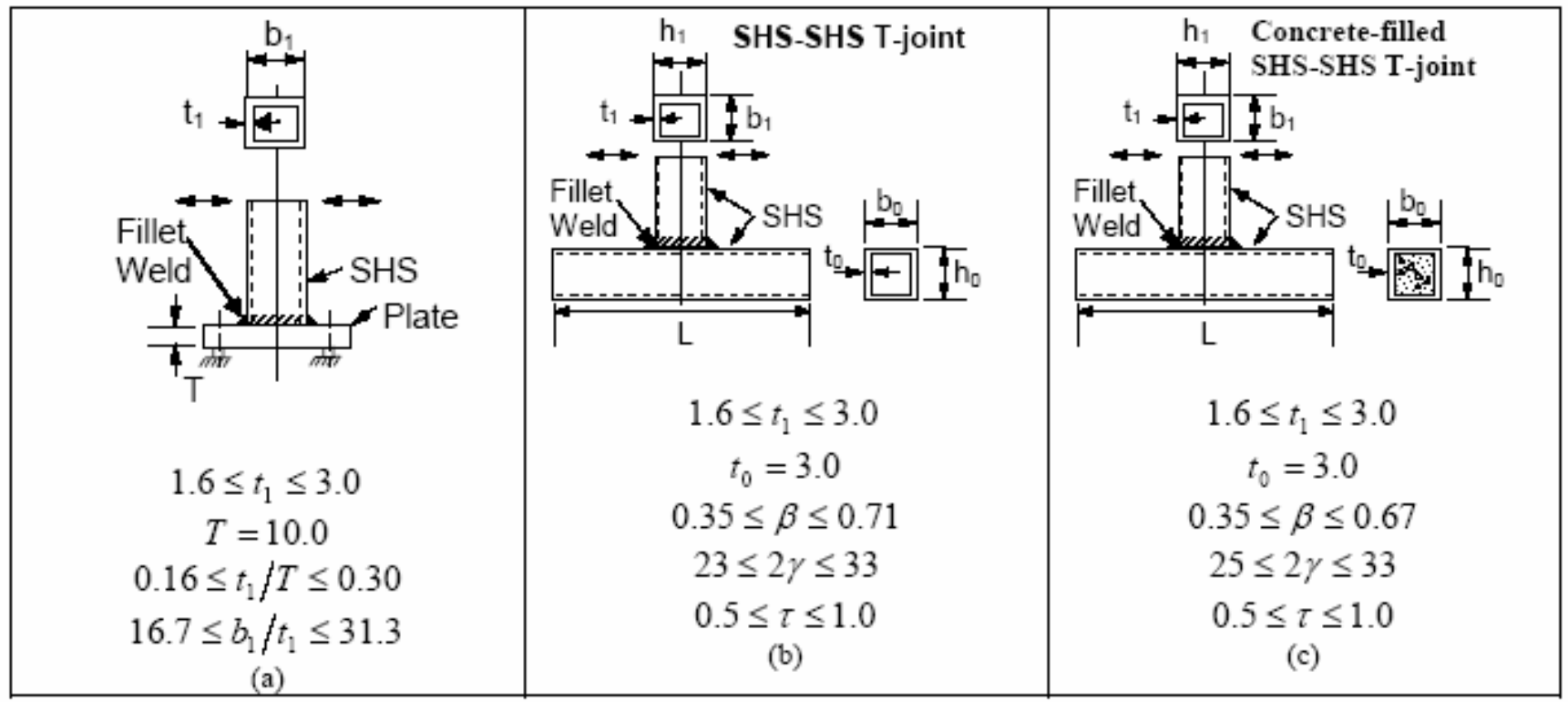

Fig. 8. (a) SHS-Plate (bolted to rigid plate), (b) Empty SHS-SHS (simply supported at both ends) and (c) Concrete-filled chord SHS-SHS T-joints under in-plane bending (simply supported at both ends) 


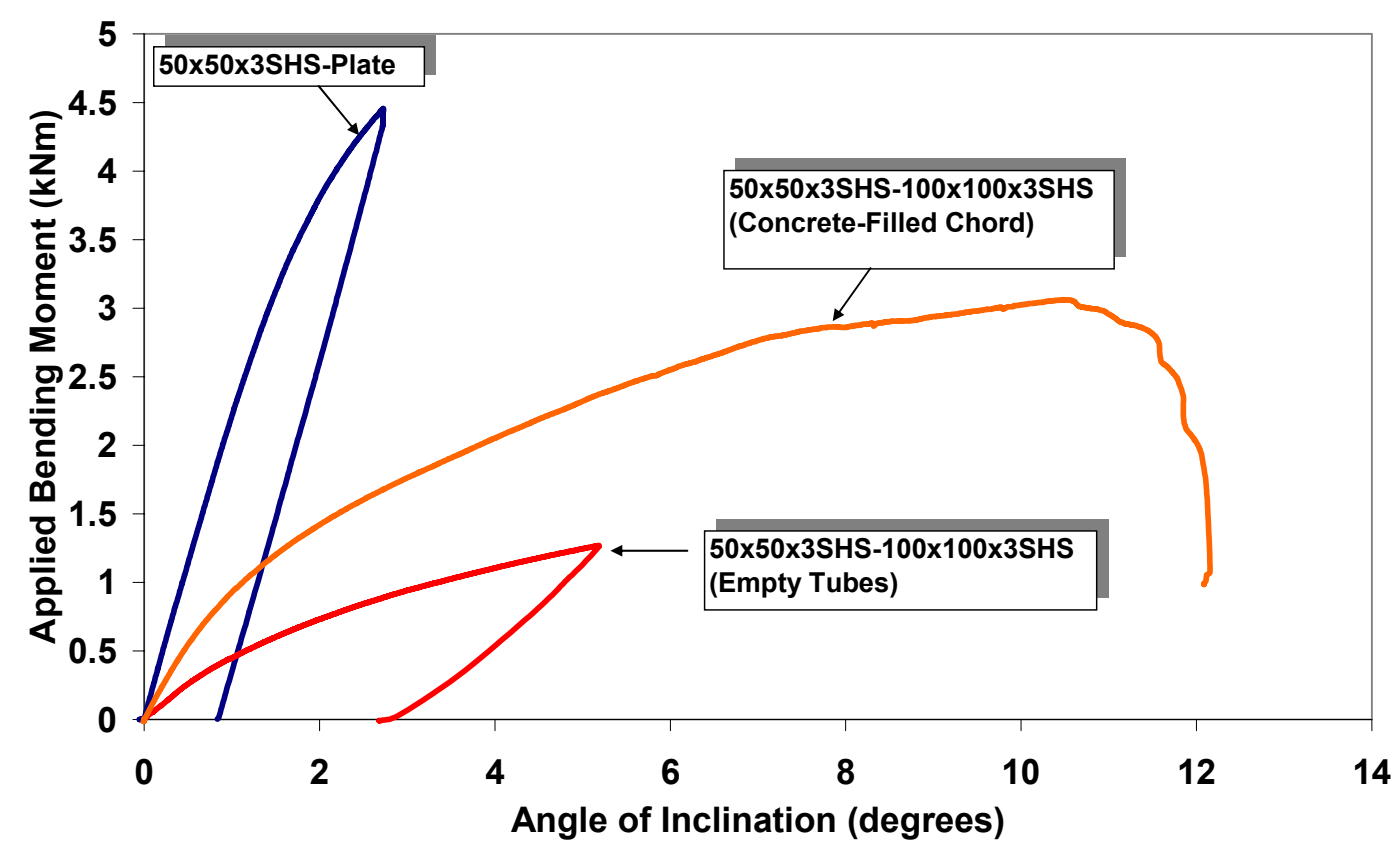

Fig. 9. Applied bending moment vs angle of inclination in joints of different stiffness

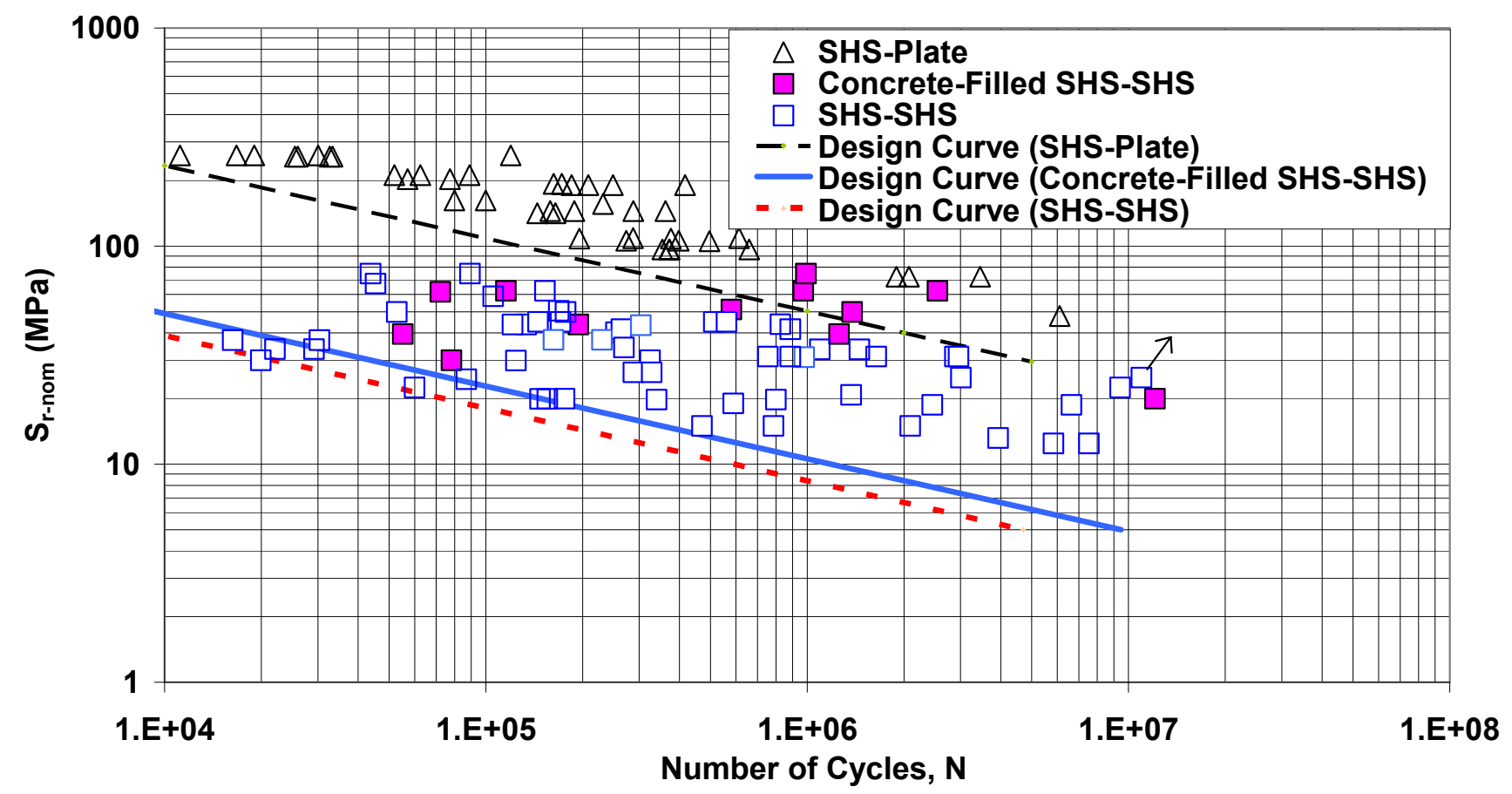

Fig. 10. S-N data and lower bound curves for thin SHS-Plate, SHS-SHS and concrete-filled SHS-SHS T-joints 
TABLES 
Table 1. Summary of Research on Size Effect

\begin{tabular}{|c|c|c|c|c|c|c|c|}
\hline Reference & $\begin{array}{c}\text { Type of } \\
\text { Connection }\end{array}$ & Loading & $\begin{array}{l}\text { Specimen Thickness } \\
\text { (mm) }\end{array}$ & Test/Analysis Condition & $\begin{array}{l}\text { Thickness } \\
\text { Correction } \\
\text { Factor } \\
\text { proposed }\end{array}$ & $\begin{array}{l}\text { Category of } \\
\text { Scaling }\end{array}$ & $\begin{array}{l}\text { Complete or } \\
\text { Partial } \\
\text { Thickness } \\
\text { Effect } \\
\end{array}$ \\
\hline \multirow[t]{2}{*}{$\begin{array}{l}\text { Mohaupt et al }{ }^{28} ; \\
\text { Vosikovsky et al }^{3}\end{array}$} & \multirow[t]{2}{*}{ Plate T-joints } & $\begin{array}{l}\text { 3-point bending; constant } \\
\text { and variable amplitude in air; }\end{array}$ & $16,26,52,78,103$ & $\begin{array}{l}\text { Joints tested in the as welded } \\
\text { condition. Stress ratio; } \mathrm{R}=0.05 \text {; } \\
\text { Joints with proportional and non- } \\
\text { proportional scaling tested; } \\
\text { improved weld profile tested }\end{array}$ & - & $\begin{array}{l}\text { Practical } \\
\text { proportional } \\
\text { Scaling }\end{array}$ & $\begin{array}{c}\text { Partial } \\
\text { Thickness Effect }\end{array}$ \\
\hline & & $\begin{array}{l}\text { 3-point bending; constant } \\
\text { amplitude in seawater }\end{array}$ & 26,78 & $\begin{array}{l}\text { Joints tested in the as-welded } \\
\text { condition in seawater were } \\
\text { unprotected, optimum } \\
\text { cathodically protected and } \\
\text { overprotected. }\end{array}$ & - & $\begin{array}{l}\text { Practical } \\
\text { proportional } \\
\text { Scaling }\end{array}$ & $\begin{array}{c}\text { Partial } \\
\text { Thickness Effect }\end{array}$ \\
\hline Booth $^{29}$ & Plate T-joints & $\begin{array}{l}\text { 4-point bending; constant } \\
\text { amplitude in air }\end{array}$ & $25,38,50,75,100$ & $\begin{array}{l}\text { Joints tested in the as-welded } \\
\text { condition, after PWHT and toe- } \\
\text { grounding; R=0 }\end{array}$ & - & $\begin{array}{l}\text { Practical } \\
\text { proportional } \\
\text { Scaling }\end{array}$ & $\begin{array}{c}\text { Partial } \\
\text { Thickness Effect }\end{array}$ \\
\hline Berge at al ${ }^{30}$ & Plate T-joints & $\begin{array}{l}\text { Cantilever loading system; } \\
\text { constant amplitude in air }\end{array}$ & $20,100,150$ & $\begin{array}{l}\text { Joints tested in as welded } \\
\text { condition }\end{array}$ & - & $\begin{array}{l}\text { Practical } \\
\text { proportional } \\
\text { Scaling } \\
\end{array}$ & $\begin{array}{c}\text { Partial } \\
\text { Thickness Effect }\end{array}$ \\
\hline \multirow[t]{2}{*}{$\begin{array}{l}\text { Overbeeke and } \\
\text { Wildschut }^{23}\end{array}$} & \multirow[t]{2}{*}{ Plate T-joints } & $\begin{array}{l}\text { Pure bending; constant } \\
\text { amplitude in air }\end{array}$ & $16,25,40,70$ & Joints tested after PWHT & See Note 1 & $\begin{array}{l}\text { Practical } \\
\text { proportional } \\
\text { Scaling }\end{array}$ & $\begin{array}{c}\text { Partial } \\
\text { Thickness Effect }\end{array}$ \\
\hline & & $\begin{array}{l}\text { Pure bending; constant } \\
\text { amplitude in seawater }\end{array}$ & 16,40 & $\begin{array}{l}\text { Joints tested in the as-welded } \\
\text { condition, after toe grinding; } \\
\text { Seawater temperature showed no } \\
\text { influence. }\end{array}$ & - & $\begin{array}{l}\text { Practical } \\
\text { proportional } \\
\text { Scaling }\end{array}$ & $\begin{array}{c}\text { Partial } \\
\text { Thickness Effect }\end{array}$ \\
\hline Xue et al ${ }^{14}$ & $\begin{array}{c}\text { Cruciform } \\
\text { welded joints }\end{array}$ & $\begin{array}{l}\text { 4-point bending, cantilever } \\
\text { bending; constant amplitude } \\
\text { in air, seawater with and } \\
\text { without cathodic protection }\end{array}$ & $16,32,40$ & $\begin{array}{c}\text { Joints tested in the as welded } \\
\text { condition at a stress ratio, } \mathrm{R} \text { of }-1\end{array}$ & See Note 2 & $\begin{array}{l}\text { Practical } \\
\text { proportional } \\
\text { Scaling }\end{array}$ & $\begin{array}{c}\text { Partial } \\
\text { Thickness Effect }\end{array}$ \\
\hline
\end{tabular}

\begin{tabular}{|c|c|}
\hline Note 1: & The thickness effect for connections in the stress relieved condition is $S=S_{B}\left(t_{B} / t\right)^{0.15}$. \\
\hline Note 2: & $\begin{array}{l}\text { The thickness correction factors proposed are as follows: In air, } S=S_{B}\left(t_{B} / t\right)^{1 / 3} \text {; Freely corroding in sea-water, } S=S_{B}\left(t_{B} / t\right)^{1 / 4} \text {; In sea-water with cathodic protection(- } \\
850 \mathrm{mV} \text {. SCE), } S=S_{B}\left(t_{B} / t\right)^{1 / 2}\end{array}$ \\
\hline
\end{tabular}


Table 1 (cont). Summary of Research on Thickness Effect

\begin{tabular}{|c|c|c|c|c|c|c|c|}
\hline Reference & Type of Joint & Loading & $\begin{array}{l}\text { Thickness Range } \\
\text { (mm) }\end{array}$ & Test/Analysis Condition & $\begin{array}{l}\text { Thickness } \\
\text { Correction } \\
\text { Factor } \\
\text { proposed }\end{array}$ & $\begin{array}{l}\text { Category of } \\
\text { Scaling }\end{array}$ & $\begin{array}{l}\text { Complete or } \\
\text { Partial } \\
\text { Thickness } \\
\text { Effect } \\
\end{array}$ \\
\hline Orjasaeter et al $^{20}$ & Plate T-joints & $\begin{array}{l}\text { Cantilever bending; 3-point } \\
\text { bending; constant amplitude } \\
\text { in air }\end{array}$ & $30,70,100,130,160$ & $\begin{array}{c}\text { Joints tested in as welded } \\
\text { condition and after PWHT; R=0.1 }\end{array}$ & - & $\begin{array}{l}\text { Practical } \\
\text { proportional } \\
\text { Scaling }\end{array}$ & $\begin{array}{c}\text { Partial } \\
\text { Thickness Effect }\end{array}$ \\
\hline Noordhoek et al $^{31}$ & Plate T-joints & $\begin{array}{l}\text { 4-point bending; constant } \\
\text { amplitude in air }\end{array}$ & $\begin{array}{c}\text { Main plate } t=70 \text { and } \\
160 \mathrm{~mm} \text { with } \\
\text { transverse/longitudin } \\
\text { al plates of } t=20 \text { and } \\
45 \mathrm{~mm} .\end{array}$ & $\begin{array}{c}\text { Joints tested in the as welded } \\
\text { condition; Thickness effect due to } \\
\text { non-proportional scaling of main } \\
\text { and attachment plate thickness; } \\
\mathrm{R}=0 \text {. }\end{array}$ & - & $\begin{array}{l}\text { Non- } \\
\text { Proportional } \\
\text { Scaling }\end{array}$ & $\begin{array}{c}\text { Partial } \\
\text { Thickness Effect }\end{array}$ \\
\hline Gurney $^{2}$ & $\begin{array}{l}\text { Plates with } \\
\text { longitudinal } \\
\text { edge } \\
\text { attachments }\end{array}$ & Tensile cyclic loading & $\begin{array}{l}\text { Width between } \\
\text { longitudinal } \\
\text { attachments, } W=40 \\
80,125,200 \\
\end{array}$ & $\begin{array}{l}\text { Joints tested in a stress relieved } \\
\text { condition, } \mathrm{R}=0 .\end{array}$ & See Note 3 & $\begin{array}{l}\text { Non- } \\
\text { Proportional } \\
\text { Scaling }\end{array}$ & $\begin{array}{c}\text { Partial } \\
\text { Thickness Effect }\end{array}$ \\
\hline Eide and Berge $^{32}$ & Plate Girders & 4-point bending & $20,40,60$ & $\begin{array}{l}\text { Joints tested in the as-welded } \\
\text { condition }\end{array}$ & - & $\begin{array}{l}\text { Non- } \\
\text { Proportional } \\
\text { Scaling } \\
\end{array}$ & $\begin{array}{c}\text { Partial } \\
\text { Thickness Effect }\end{array}$ \\
\hline Van Delft et al ${ }^{33}$ & $\begin{array}{l}\text { Tubular T-, } \\
\text { Y-, X-, K- \& } \\
\text { KT- joints }\end{array}$ & $\begin{array}{l}\text { Axial, in-plane bending and } \\
\text { out-of-plane bending }\end{array}$ & $10,20,40,80,160$ & $\begin{array}{l}\text { Joints tested in the as-welded and } \\
\text { stress relieved conditions; Data } \\
\text { from } 200 \text { specimens analysed }\end{array}$ & See Note 4 & $\begin{array}{l}\text { Non- } \\
\text { Proportional } \\
\text { Scaling } \\
\end{array}$ & $\begin{array}{c}\text { Partial } \\
\text { Thickness Effect }\end{array}$ \\
\hline Van Wingerde et $\mathrm{al}^{5}$ & $\begin{array}{l}\text { Tubular T-, } \\
\text { Y-, X-, \& K- } \\
\text { joints }\end{array}$ & $\begin{array}{l}\text { Axial, in-plane bending and } \\
\text { out-of-plane bending; Tested } \\
\text { in air }\end{array}$ & $\begin{array}{c}4,5,8,10,12,16,25 \\
32,50\end{array}$ & $\begin{array}{c}\text { Data from } 238 \text { specimens } \\
\text { analysed }\end{array}$ & See Note 5 & $\begin{array}{l}\text { Non- } \\
\text { Proportional } \\
\text { Scaling } \\
\end{array}$ & $\begin{array}{c}\text { Partial } \\
\text { Thickness Effect }\end{array}$ \\
\hline IIW $^{34}$ & $\begin{array}{l}\text { Cruciform } \\
\text { Joints }\end{array}$ & Axial & $\begin{array}{c}\text { Thickness greater } \\
\text { than or equal to } \\
25 \mathrm{~mm} \\
\end{array}$ & $\begin{array}{l}\text { Joints tested in the as welded, toe } \\
\text { ground }\end{array}$ & See Note 6 & $\begin{array}{l}\text { Non- } \\
\text { Proportional } \\
\text { Scaling } \\
\end{array}$ & $\begin{array}{c}\text { Partial } \\
\text { Thickness Effect }\end{array}$ \\
\hline
\end{tabular}

\begin{tabular}{|c|c|}
\hline Note 3: & $\begin{array}{l}\text { Gurney }{ }^{2} \text { suggested from the limited test data that joints with an attachment on or adjacent to the edge of the plate under a stress range could be corrected by } S=S_{B}\left(W_{B} / W^{\prime}\right)^{\frac{1}{4}} \\
\text { where, } W_{B} \text { is the basic width corresponding to the basic design } \mathrm{S}-\mathrm{N} \text { curve }\left(W_{B}=100 \mathrm{~mm}\right), W^{\prime} \text { is the apparent width of the plate under consideration. Gurney }{ }^{2} \text { also suggested } \\
\text { that } W^{\prime}=W \text {, if } L>W \text { or } W^{\prime}=L \text { if } L<W \text {, where } W \text { is the actual plate width and } L \text { is the attachment length in the direction of stress. }\end{array}$ \\
\hline Note 4: & $\begin{array}{l}\text { The relation between the hot spot strain range (HSSNR), number of cycles to crack through }\left(N_{c}\right) \text { and the wall thickness of the cracked member }\left(T_{c r}\right) \text { from the regression analysis was } \\
\text { found to be, } \log H S S N R=4.53-0.175 \cdot \log N_{c}+0.075 \cdot \log N_{c} \cdot \log T_{c r} \text {. }\end{array}$ \\
\hline Note 5: & Thickness correction is based on statistical analysis of the database and is of the form: $S_{r h s, t}=S_{r h s, 16} \cdot(16 / t)^{-0.06 \cdot \log N}$ \\
\hline Note 6 & Thickness correction is of the form, $S=S_{B} \cdot\left(25 / t_{\text {eff }}\right)^{n}$, see Section 3.5.2.2 of IIW ${ }^{34}$ for further details. \\
\hline
\end{tabular}


Table 2. Size effect in existing standards using classification method (some examples)

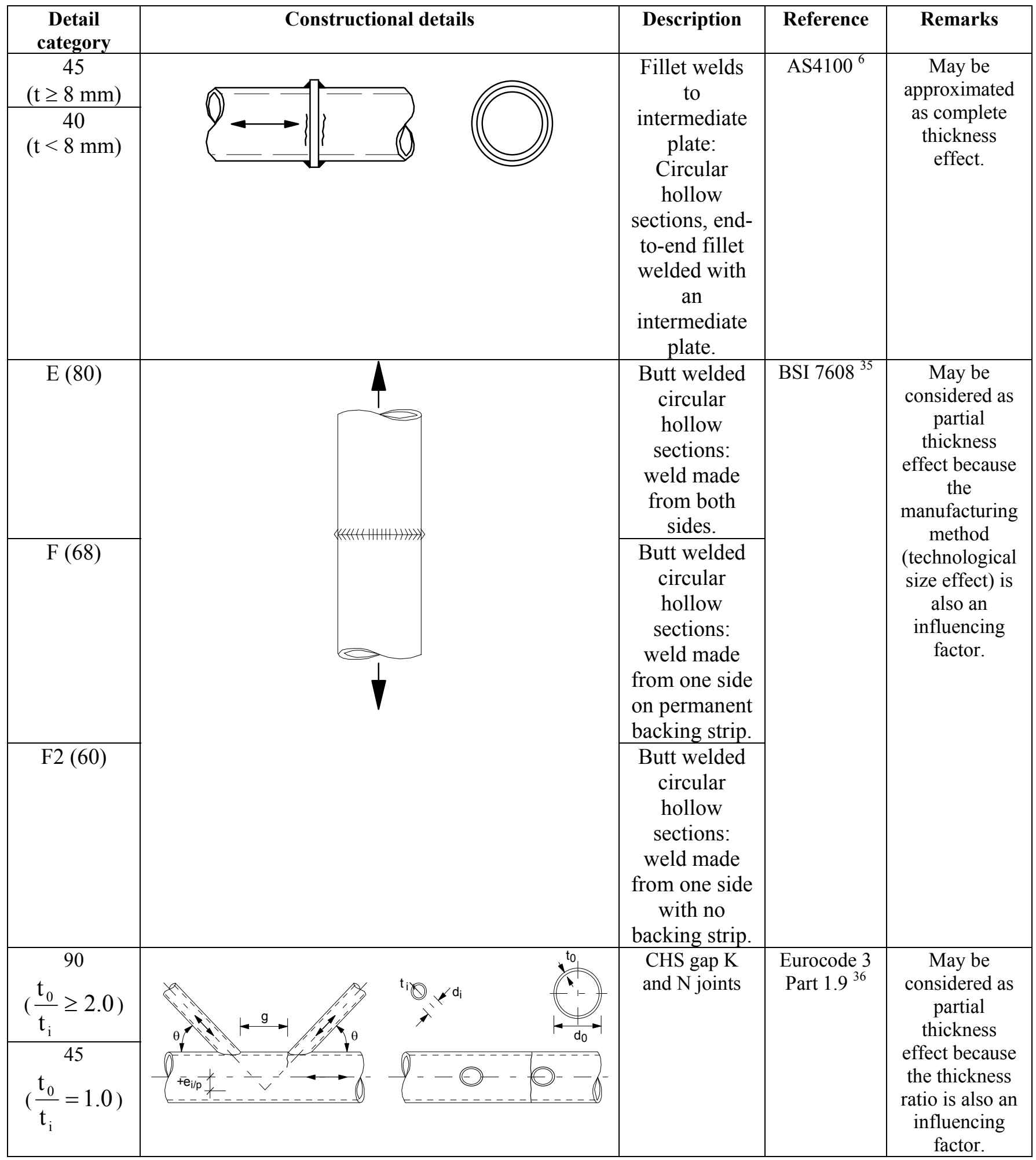


Table 3. Size effect in existing standards using hot spot stress method

\begin{tabular}{|c|c|c|c|c|c|}
\hline $\begin{array}{c}\text { Type of } \\
\text { Joints }\end{array}$ & $\begin{array}{c}\text { Thickness } \\
\text { correction factor }\end{array}$ & Description & SCFs & References & Remarks \\
\hline $\begin{array}{l}\text { Uniplanar T, } \\
\text { X, Y, K } \\
\text { tubular joints } \\
\text { and } \\
\text { multiplanar } \\
\text { XX, KK } \\
\text { tubular joints }\end{array}$ & $S=S_{B} \cdot(16 / t)^{-0.06 \cdot \log N}$ & $\begin{array}{l}\text { Design S-N curves in the hot spot stress } \\
\text { method are defined by the following } \\
\text { equations for different tube wall } \\
\text { thicknesses: } \\
\log (\mathrm{N})=\frac{12.476-3 \cdot \log \left(\mathrm{S}_{\mathrm{rhs}}\right)}{1-0.18 \cdot \log (16 / \mathrm{t})} \text { for } \\
10^{3}<\mathrm{N}<5 \cdot 10^{6} \text { and } \\
\log (\mathrm{N})=16.327-5 \cdot \log \left(\mathrm{S}_{\mathrm{rhs}}\right)+2.01 \cdot \log (16 / \mathrm{t}) \\
\text { for } 5 \cdot 10^{6}<\mathrm{N}<10^{8} \text { (for variable } \\
\text { amplitude only) } \\
\text { Equations for hot spot S-N curves for } \\
\text { CHS joints }(4 \mathrm{~mm} \leq t \leq 50 \mathrm{~mm}) \text { and RHS } \\
\text { joints }(4 \mathrm{~mm} \leq t \leq 16 \mathrm{~mm})\end{array}$ & $\begin{array}{l}\text { A function } \\
\text { of } \beta, 2 \gamma \\
\text { and } \tau \text {. }\end{array}$ & $\begin{array}{l}\text { IIW }^{16} \text { and } \\
\text { Zhao et al }{ }^{17}\end{array}$ & $\begin{array}{l}\text { May be } \\
\text { considered } \\
\text { as partial } \\
\text { thickness } \\
\text { effect } \\
\text { because } \\
\text { other } \\
\text { parameters } \\
(\beta, 2 \gamma \text { and } \\
\tau) \text { are also } \\
\text { influencing } \\
\text { factors. }\end{array}$ \\
\hline
\end{tabular}

Table 4. Experimental stress concentration factors in thin SHS-SHS T-joints and concrete-filled chord SHS T-joints under in-plane bending

\begin{tabular}{|c|c|c|c|c|c|c|c|c|}
\hline \multirow[t]{2}{*}{$\begin{array}{l}\text { Series } \\
\text { Name }\end{array}$} & \multirow[t]{2}{*}{$\begin{array}{c}\text { Chord member } \\
\mathbf{b}_{0} \mathbf{x h}_{0} \mathbf{x t}_{0}\end{array}$} & \multirow{2}{*}{$\begin{array}{c}\text { Brace } \\
\text { member } \\
\mathbf{b}_{1} \mathbf{x h}_{1} \mathbf{x t}_{1}\end{array}$} & \multicolumn{3}{|c|}{ Non-dimensional parameters } & \multicolumn{2}{|c|}{$\begin{array}{c}\text { Maximum measured } \\
\text { SCFs }\end{array}$} & \multirow{2}{*}{$\begin{array}{c}\text { Ratio of } \\
\text { Max. } \\
\text { SCFs } \\
S C F_{\text {Composite }} \\
S C F_{\text {Empty }}\end{array}$} \\
\hline & & & $\begin{array}{c}\beta \\
=\frac{b_{1}}{b_{0}}\end{array}$ & $\begin{array}{c}\tau \\
\left.=\frac{t_{1}}{t_{0}}\right)\end{array}$ & $\left(\begin{array}{c}2 \gamma \\
=\frac{b_{0}}{t_{0}}\end{array}\right)$ & $\begin{array}{l}\text { Concrete- } \\
\text { filled } \\
\text { chord } \\
\text { SHS T- } \\
\text { joints }\end{array}$ & $\begin{array}{c}\text { Empty } \\
\text { SHS-SHS } \\
\text { T-joints }\end{array}$ & \\
\hline S3S1 & 100x100x3SHS & 50x50x3SHS & 0.50 & 1.00 & 33.3 & 8.0 & 12.0 & 0.67 \\
\hline S3S2 & 100x100x3SHS & 50x50x1.6SHS & 0.50 & 0.53 & 33.3 & 6.4 & 7.1 & 0.90 \\
\hline S3S4 & 100x100x3SHS & $35 \times 35 \times 3$ SHS & 0.35 & 1.00 & 33.3 & 6.3 & 12.7 & 0.50 \\
\hline S3S5 & 100x100x3SHS & $35 \times 35 \times 1.6 \mathrm{SHS}$ & 0.35 & 0.53 & 33.3 & 4.8 & 5.9 & 0.81 \\
\hline S6S1 & $75 \times 75 \times 3 \mathrm{SHS}$ & 50x50x3SHS & 0.67 & 1.00 & 25.0 & 10.8 & 8.4 & 1.29 \\
\hline S6S2 & $75 \times 375 \times 3 \mathrm{SHS}$ & $50 \times 50 \times 1.6 \mathrm{SHS}$ & 0.67 & 0.53 & 25.0 & 2.5 & 8.3 & 0.30 \\
\hline
\end{tabular}

Table 5. Experimental stress concentration factors for thin SHS-Plate T-joints

\begin{tabular}{|c|c|c|c|c|c|}
\hline $\begin{array}{c}\text { Series } \\
\text { Name }\end{array}$ & Brace Member & Plate Size & $\left(=\frac{t_{1}}{t_{P}}\right)$ & $\left(=\frac{b_{1}}{t_{1}}\right)$ & $\begin{array}{c}\text { Maximum } \\
\text { measured SCFs }\end{array}$ \\
\hline S1P & $50 \times 50 \times 3$ SHS & $190 \times 190 \times 10 \mathrm{PL}$ & 0.30 & 16.7 & 1.8 \\
\hline S2P & $50 \times 50 \times 1.6 \mathrm{SHS}$ & $190 \times 190 \times 10 \mathrm{PL}$ & 0.16 & 33.3 & 1.6 \\
\hline D7P & $40 \times 40 \times 2$ SHS & $190 \times 190 \times 10 \mathrm{PL}$ & 0.20 & 20 & 1.6 \\
\hline
\end{tabular}

